NBER WORKING PAPER SERIES

\title{
FROM FORCED BUSING TO FREE CHOICE IN PUBLIC SCHOOLS: QUASI-EXPERIMENTAL EVIDENCE OF INDIVIDUAL AND GENERAL EFFECTS
}

\author{
Victor Lavy \\ Working Paper 11969 \\ http://www.nber.org/papers/w11969
NATIONAL BUREAU OF ECONOMIC RESEARCH 1050 Massachusetts Avenue
Cambridge, MA 02138
January 2006

I have benefitted from helpful discussions with Josh Angrist, Clark Damon, Rachel Friedberg, Brian Jacob, Inger Munk, Daniele Passerman, Jesse Rothstein, Doug Staiger, and comments of seminar participants at Dartmouth College, Hebrew University, UCL, Princeton University, Tel Aviv University and the Public Policy and the Labor Program CEPR conferences. I am grateful to Shmuel Dorfman for guiding me through the details and documents of the Tel Aviv school-choice program, which was designed and implemented during his tenure as director of the Tel Aviv Municipal Education and Culture Administration. I would like to thank the Ministry of Education for assisting with the data and Alex Levkov, Issi Romem and Orit Vaaknin for expert research assistance. I also gratefully acknowledge funding from Forum Sapir and the Israel National Academy Foundation. The views expressed herein are those of the author(s) and do not necessarily reflect the views of the National Bureau of Economic Research.

(O)2006 by Victor Lavy. All rights reserved. Short sections of text, not to exceed two paragraphs, may be quoted without explicit permission provided that full credit, including $\odot$ notice, is given to the source. 
From Forced Busing to Free Choice in Public Schools: Quasi-Experimental Evidence of Individual and General Effects

Victor Lavy

NBER Working Paper No. 11969

January 2006

JEL No. I20, J24

\begin{abstract}
$\underline{\text { ABSTRACT }}$
In 1994 the city of Tel Aviv replaced its existing school integration program based on inter-district busing, with a new program that allowed students to choose freely between schools in and out of district. This paper explores the impact of this program on high school outcomes while distinguishing the effect of choice on individual students from general equilibrium effects on affected districts. The identification is based on a regression discontinuity design that yields comparison groups drawn from untreated tangent neighborhoods in adjacent cities and on instrumental variables. The results suggest that the choice program had significant general equilibrium effects on high school dropout rates, matriculation rates and program of study. The gains are more pronounced among disadvantaged children but not among students who took advantage of the option to attend out of district schools with higher mean outcomes. These results and other evidence related to the behavioral responses of schools and students to the program suggest that the positive impact of the program is mainly due to better matching between students and schools and to productivity effects of choice and competition among schools.
\end{abstract}

\author{
Victor Lavy \\ Department of Economics \\ Hebrew University \\ Mount Scopus \\ 91905 Israel \\ and NBER \\ msvictor@huji.ac.il
}




\section{Introduction}

Recent education reforms in many countries aim at improving educational outcomes by expanding parental choice among public schools. Such system-wide school choice programs may have general effects that improve school quality through enhanced competition or through better matching between students and schools. Most of the research on the general effect of choice in the US has looked at housing markets as representative of a potentially informative form of school choice which allow establishing indirectly its relationship with school quality or productivity (Black 1999, Hoxby 2000 and 2005 and Rothstein 2004a and 2004b). Studies on other countries used general school reforms to examine the effect of competition and choice on school performance (Ahlin 2003, and Sandstrom and Berstrom 2002 are studies on the choice reform in Sweden; Bradley, Johnes and Millington 2001, Clark 2005, and Gibbons, Machin and Silva 2005, in the UK; Chang and Urquiola 2003, in Chile; and Fiske and Ladd 2000, in New Zealand). Other related research studied programs that allowed specific groups to attend private or charter schools and estimated partial equilibrium effects of choice on individuals (for example, Rouse 1998, Peterson et al. 1998, Mayer et al. 2002, Angrist et al. 2002, Krueger and Zhu 2004, Cullen, Jacob and Levitt 2005, Hoxby 2005). Some programs allowed public school students to apply to magnet and public schools outside of their neighborhood (Cullen, Jacob and Levitt 2003). However, the more complete characterization of the effect of school choice, including both the general and individual effects, is still an open question and this study takes a step in this direction.

This paper looks directly at both the general and individual effects of public school choice by exploiting a policy reform that allowed open and choice-based enrollment in post-primary schooling in Tel Aviv, Israel. The program allowed students to choose between schools in and out of their district, therefore permitting to distinguish between the general effects on affected districts from the individual effect of opting out of neighborhood schools. Prior to this program, which started in 1994, enrollment was based on zoning, including compulsory inter-school district busing of about 40 percent of the students. This aspect of reverse desegregation, i.e., the replacement of busing with free choice, makes the Tel Aviv choice similar to recent programs in the U.S where forced busing was replaced with free school choice. ${ }^{1}$

The Tel Aviv School Choice Program (hereafter, TASCP) allowed students choice among five secondary schools, three in their school district and two from more affluent neighborhoods in the city. In this paper I focus on the school district that was enrolled first into the program (district 9). I follow students from the end of primary school (sixth grade) to the end of high school (twelfth grade) which allows, unlike most research in this area, to estimate the impact of school choice on long-term academic

\footnotetext{
${ }^{1}$ Many of these choice programs are part of a federal court agreement granting a school district "Unitary Status." Examples are The Charlotte-Mecklenburg (North Carolina) and the Pinellas County, Florida, choice programs (among the largest school districts in the U.S). Examples of earlier programs are Montclair, NJ, Cambridge, MA, and 17 other districts in Massachusetts.
} 
outcomes. Because disadvantaged students were overrepresented in schools that were included in the early phases of the choice program, TASPC allows exploring the impact of school choice in an environment about which there is heightened concern. Another distinguishing feature of this paper is its focus on the effect of choice on measures of educational achievement that are key determinants of post-secondary schooling and market wages in Israel.

In the first part of the paper I estimate the general effect of the choice program. The non-random selection of district 9 to the program eliminates an estimation strategy based on a simple exposure to the program. However, since district 9 is located at the eastern edge of Tel Aviv, bordering two adjacent cities of the same metropolitan area, Giv'atayim and Ramat Gan (hereafter, GR), a regression discontinuity strategy based on a sample drawn from a narrow band around the municipal border can produce a treatment-control contrast that will allow causal interpretation of the effect of the program. Indeed, limiting the sample to observations within such narrow bandwidth yields a perfectly balanced sample between treatment and control. Such an RD or natural experiment strategy (which is similar to one used by Black 1999) will most likely remove any heterogeneity across district 9 an GR that may confound the effect of the choice-program estimates. Within this RD-natural experiment framework I also use paneldata and implement difference-in-differences estimation which helps as well to eliminate constant baseline unobservable differences that may confound the effect of choice. Using these various identification methods consistently suggests that the school-choice program led to a sharp reduction in the dropout rate and to significant improvement in matriculation-exam outcomes.

The positive general equilibrium effects of the program may reflect positive partial equilibrium effect of students who chose to opt out and attend better schools (in terms of mean outcomes) in North Tel Aviv and positive effect from enhanced competition and better matching between students and schools. In the second part of the paper I use an instrumental variable strategy to assess how important is the opting out channel in explaining the general equilibrium effect of choice. The first instrument that I use exploit a special feature of the program: students who opted out of district 9 were provided with transportation to the school of their choice while students who stayed in district 9 schools had to use public transportation. Based on this difference in convenience of transportation to school, the first instrument I use is an indicator of whether a student resides on a street that is served by a public bus line that leads to one of the three secondary schools in district 9. I show that the two groups formed by dividing the treated students according to this indicator are balanced in all observable dimensions. However, those who reside on streets with such bus lines have a significantly higher probability of choosing a school in their district. I also use a related instrument, the distance from home to the nearest school in district 9. This instrument has a very strong and significant first stage, affecting negatively the probability of opting out, and it is also well balanced in terms of observable characteristics. As a third alternative, I also use as an instrument the intersection of two unrelated indicators; the first is an indicator of whether a student has an older 
sibling of a middle school age and the second is whether this sibling is assigned for busing to schools outside of district 9. Students who meet these two criteria might have higher propensity to opt out due to convenience, safety, and considerations of similar nature. I show that the two groups formed by this indicator are also balanced in all observable dimensions while the instrument has a strong first-stage effect, almost a 60 percent higher probability of opting out.

Contrary to the OLS results, the IV results suggest that opting out or remaining in neighborhood schools did not lead to a differential effect of the choice program on students' long-term outcomes. These results resemble the evidence shown by Cullen, Jacob Levitt, 2004 and 2005, who find no academic effect of opting out from own district schools in the Chicago public school system. This result suggests that much of the general equilibrium effect of choice is related to the enhanced competition among schools and the better match between students and schools facilitated by the program. This interpretation of the evidence is supported by research findings about the behavioral response of students and schools to the program. The rest of the paper is structured as follows: section II presents the background and details of TASCP and gives some preliminary information about the pattern of choice and section III describes the data. Section IV describes the identification strategy and the estimates of the general equilibrium effects of the choice program, section $\mathrm{V}$ presents the individual effects of opting out versus staying in neighborhood schools and of busing students to out of district schools, section VI discusses the results and alternative explanations and section VII concludes.

\section{The Tel Aviv School-Choice Program}

\section{Background and the Structure of School Choice}

In May 1994, the Israeli Ministry of Education and Government approved TASCP as a two-year experiment to be implemented in the city's school district 9. It was the first choice program in the country since the 1968 education reform that enacted compulsory integration in grades 7-9. ${ }^{2}$ TASCP was a response to the dissatisfaction of parents with students' outcomes and the lack of school choice. Its objectives were to give disadvantaged students access to better schools, facilitate a better match between students and schools, and motivate school productivity improvements through competition and enhanced accountability.

District 9 includes sixteen public primary schools, twelve secular and four religious. Until 1994 the graduates of five of the secular primary schools were bused to one of five secondary schools in the northern parts of the city (districts 1-4). The graduates of the other seven secular primary schools were assigned to one of the two secondary schools in district 9. In May 1994 the Education board of Tel Aviv

\footnotetext{
${ }^{2}$ The 1968 reform established a three-tier structure of schooling: primary (grades 1-6), middle (7-9), and high school (10-12). The reform established zoning of neighborhood schools as the basis of primary enrollment,
} 
announced that as of September 1994 this system will be replaced by free choice for the incoming $7^{\text {th }}$ graders in district 9 while older cohorts will continue in the old system.

The structure of choice was as follows. By end of sixth grade each student was asked to rank his preference among the five schools in his choice set which included always the three secondary schools in district 9 and two of the nine secondary schools of districts $1-4$. The choice set varied among students in accordance with the primary school they attended. ${ }^{3}$ In case of excess demand for a particular school, students were assigned to schools in a manner that maintained socio-economic balance that matched the respective makeup of the city. ${ }^{4}$ However, the city reports that in the first year of the program 90 percent of students received their first choice, others their second choice; in the second year the respective rate was even higher ${ }^{5}$; since 2003 excess demand is resolved by a lottery.

The experiment was expanded to district 8 three years later and to the rest of the city from the fourth year (Tel Aviv Education Authority, 2001). During the first four years of the program, two evaluation teams provided useful and important insights on the educational and social changes that took place in schools and among teachers, students, and parents. Heiman and Shapira $(1998,2002)$ provide detailed summaries of the program and the changes observed over the years. However, the long-term impact of the program has not been studied.

\section{Sorting and Opting to out of District 9's Schools}

Levy, A., et al., $(1996,1997)$ describes the pattern of choice by students' pre-program achievement. 38 percent of the students in district 9 opted out in the first and second year of the program. ${ }^{6}$ The respective rates among students from the five schools that otherwise would have been bused were much higher, 68 percent in both years. ${ }^{7}$ The students who opted had on average higher pre-program test scores though some of the least able students opted out as well (Levy et al., 1998). In the third year, however, the distribution was more balanced: about half of average and good students in District 9 remained in neighborhood schools while the rest chose schools in Districts $1-4 .^{8}$

integration and busing of students out of their neighborhoods in middle schools, and municipal discretion in regard to enrollment in high schools. In Tel Aviv, most middle schools were part of six-year high schools.

${ }^{3}$ The distance from each of the twelve primary schools in district 9 to the closer of the two schools included in the choice set varied greatly, from one to nine kilometers. The maximum distance to the three schools in district 9 was 4 kilometers.

${ }^{4}$ Siblings in the same school and school capacity were also used as criteria to balance enrollment.

${ }^{5}$ Tel Aviv Education Authority (1999).

${ }^{6}$ Few students enrolled in the only two charter middle school in the city (the Science and Nature schools, both located in District 8). A small number of students enrolled in schools outside of Tel Aviv.

${ }^{7}$ Source: Tel Aviv Municipal Education and Culture Administration, Memorandum (in Hebrew), Summary Statistics from the School Choice Administration, 1994-95, May 28, 1995.

${ }^{8}$ This more balanced pattern in the propensity to opt out reflected perhaps the city's education authority's effort to inform parents about the benefit from choice and the options available. Schools also held "choice workshops" for parents and students. 
Lacking access to the achievement data used by Levy et al. (1996, 1997), I examined the sorting based on students' socioeconomic characteristics. The students who opted out of district 9 were from better socio-economic background as evident by their significantly higher mean fathers' years of schooling (11.7 versus 10.3), higher mothers' schooling (11.9 versus 10.5), lower proportion of students from an Asia/Africa ethnic origin (17.3 versus 22.4 percent) and higher proportion of students from a Europe/America ethnic origin (7.5 versus 2.8 percent).

\section{The Data}

The data I use in this study comes from administrative records of the Ministry of Education on the universe of Israeli primary schools in the 1992-1994 school years. The files contain an individual identifier, a school and class identifier, and the following family-background variables: father's and mother's years of schooling, number of siblings, gender, immigration status $(=1$ if arrived to the country during the last five years, which is The Ministry of Education official definition) and family ethnic origin (Asia/Africa, Europe/America and Israel) ${ }^{9}$ and the student home address. Data on distances from the student's home to the high schools included in his choice set and to the municipal border between Tel Aviv and GR were obtained from the Central Bureau of Statistics. The three cohorts on which I focus in this study had enough time within our sample period (which ends with the 2000/2001 school year) to finish high school if they progressed through the system without repeating classes.

I linked the primary-school records to individual data on high-school enrollment and matriculationexam outcomes in the 1998/99 through the 2001/02 school years. This allowed monitoring each student from the end of sixth grade (in 1992, 1993 or 1994) to the advanced stages of high school. As outcomes I use an indicator of dropping out before completing twelfth grade, passing the matriculation exams, ${ }^{10}$ credit-weighted average score on the matriculation exams, number of matriculation credits, number of matriculation credits in science subjects, and number of matriculation subjects at honors level. Several of these outcomes are used to screen and select students for prestigious universities and desired academic programs such as medicine, engineering, and computer science.

Table 1, columns 1-2, presents summary statistics for the cohort that completed primary school in June 1993 (the last cohort before the choice program started) in Tel Aviv and in district 9. Comparison of

\footnotetext{
${ }^{9}$ Israeli society is quite clearly divided along ethnic lines in terms of socioeconomic status. For example, Israeli children of Asian/African origin (i.e., born in an African or Asian country or born to parents who were born there) have the lowest average background characteristics.

${ }^{10}$ Matriculation is completed by passing a series of national exams in core and elective subjects beginning in tenth grade but most taken in twelfth grade. Students choose to be tested at various proficiency levels, each test awarding 1-5 credit units per subject depending on difficulty. A minimum of twenty credit units is required to qualify for a matriculation certificate. About half of all high-school seniors receive matriculation certificates. Similar high-school matriculation exams are found in many countries and in some U.S. states. Examples include the French Baccalaureate, the German Certificate of Maturity (Reifezeugnis), the Italian Diploma di Maturità, the New York State Regents examinations, and the recently instituted Massachusetts Comprehensive Assessment System.
} 
Column 2 with Column 1 and the t-statistics in column 3 indicate that district 9 students had lower socioeconomic characteristics than other students in Tel Aviv. For example, they have lower level of parental schooling, larger family size, a higher proportion of students from an Asia/Africa origin and lower proportion from a Europe/America origin. The lower panel of the table shows that they also had lower outcomes, for example a higher drop out rate and a lower matriculation (Bagrut) rate. Similar results are obtained when using the cohort who completed primary school in June of 1994 and enrolled first in the choice program.

\section{The General Effect of School Choice}

\section{Identification Strategy}

Tel Aviv is part of a metropolitan area that includes five major cities. Two of them, Givatayim and Ramat Gan (to be noted here as GR), are tangent to district 9 which includes all the most southeastern city's neighborhoods (see Map 1). GR have independent and separate education systems and therefore they were not part of the school choice reform of Tel Aviv. ${ }^{11}$ The metropolitan geography of district 9 and the adjacent cities raise the possibility that students in GR may be used as a comparison group for students from district 9. However, as shown in Table 1, columns 2 and 3, GR students are very different in mean characteristics from district 9 students (t-test for these differences are presented in column 5). The lower panel of this table indicates that these two groups are also very different in pre-program outcomes. However, a regression discontinuity design that limits the sample, in a manner similar to Black (1999), to observations within a narrow bandwidth around the municipality border between district 9 and GR may eliminate these imbalances because proximity of residence may be paralleled by similarity in other characteristics. Having data on pre and post program cohorts (sort of a panel data) can further enhance the identification of the causal effect of the program by enabling difference in differences estimation which can further remove any remaining time invariant heterogeneity across treated and control groups.

In this section I use both of the above methods to identify the effect of the choice program. As for the RD-natural experiment method, I define samples based on drawing symmetric bands around the municipal border starting from 100 meters (on each side) and increasing gradually (Map 2 presents an example of such a symmetric band). As will be shown below, contrary to the large imbalances based on all of district 9 and GR, the natural experiment samples based on narrow bands around the municipal border yield perfectly balanced treatment and control groups.

Figure 1 presents balancing tests for treatment-control mean differences for samples based on symmetric bands starting from 100 meters and increasing in increments of 50 meters, until 3.500 meters

\footnotetext{
${ }^{11}$ Givatayim and Ramat Gan high schools enrollment before the inception of the TASCP was based on zoning and it did not change since. The two cities did not have either any other major educational reform since 1994.
} 
and beyond. Four representative characteristics of the 1994 graduating $6^{\text {th }}$ grade cohort are presented in the figures: father and mother years of schooling, number of siblings and the proportion of students whose parents were born in Israel. The upper panel in each of the graphs presents the level of the respective characteristic for each of the two groups and the lower panel presents the estimated treatment-control difference and its 95 percent confidence interval (standard error are clustered at the primary school level). For most of the characteristics, the treatment-control differences are identically zero in the sample based on a bandwidth of 150 meters and they gradually become non-zero as the bandwidth increases but they all remain statistically not different from zero until a bandwidth of 750 meters. From about 1000 meters on the differences remain practically constant and they are significantly different from zero. However, the important conclusion drawn from the figure is that up to about 300 meters the differences are very small in absolute and in relative terms and they are also not statistically significant. ${ }^{12}$

Table 2 presents more detailed descriptive statistics and balancing tests for equality of means of the treated and the comparison groups for samples based on a bandwidth of $200^{13}$ and 250 meters and also for the full sample. Results are shown for the pre (1993) and post (1994) cohorts of treatment. Columns 1-2 present the balancing tests for the sample based on the 200 bandwidth and columns 3-4 for the 250 bandwidth. All the 16 estimates of the treatment-control differences in 1994 are not different statistically from zero and in most cases they are also very small. For example, the father's and mother's years of schooling differences in the 200 bandwidth sample are -0.377 (s.d=0.954) and -0.295 (s.d=0.943), respectively, relative to respective means of 11.4 and 11.6. Another example of the striking similarity of the two groups is reflected in the composition of students by ethnic origin: the difference in proportion of students from Asia/Africa origin is $0.012(\mathrm{~s} . \mathrm{d}=0.041)$ relative to a mean of 0.171 in the control group, and the difference in proportion of students from Europe/America origin is -0.022 (s.d=0.041) relative to 0.114 in the control group. The 1993 cohort is slightly less well balanced; of the 16 estimates of the treatment-control differences four are significantly different from zero, reflecting imbalance in proportion of immigrants and in the proportion of students from Europe/America origin, both in the 200 and the 250 bandwidth samples. However, this slight imperfect balance is likely random since, as will be shown in the next section, it is paralleled by small and non-significant pre-program treatment-control differences in outcomes which after conditioning on covariates vanish almost completely. It is therefore safe to conclude that the treatment-control contrast in the 200 or 250 bandwidth samples truly reflect a natural experiment that can be used to identify the general equilibrium effect of the choice program.

Columns 5-7 in Table 2 present the balancing tests for the full sample of 1992, 1993 and 1994. We have already seen in Figure 1 evidence of large treatment-control imbalances in the 1994 cohort and the

\footnotetext{
${ }^{12}$ The evidence for other characteristics such as immigration status and proportion of other ethnic groups are very similar and therefore are not presented in Figure 1.

${ }^{13}$ The samples based on 100-150 meters are too small though their results are presented in Figures 1 and 2.
} 
evidence in Table 2 further substantiates this pattern by showing that it also exists for the 1992 and 1993 cohorts. For example, the difference in mean years of fathers' schooling in 1992 was -1.156 and it is statistically significant ( $\mathrm{s} . \mathrm{d}=0.343$ ). The means and treatment-control contrast for 1993 , also a pretreatment year, are very similar to the evidence for 1992, as also are the evidence for 1994 (presented in column 7). This pattern suggests a remarkable stability in the composition of students in both groups over the 1992-1994 cohorts, a result that lends credibility to the use of this panel of cross sections data for differences-in-differences estimation.

\section{Estimation}

The natural experiments samples were shown above to be well balanced in student characteristic and also in preprogram outcomes. Yet, it does not preclude the possibility that differences between the two groups in unobservables still exist. Using characteristics and schooling outcomes of untreated preprogram cohorts, however, may provide a baseline for benchmarking the changes that followed the program. I will therefore first present a controlled comparison of treated and untreated students using samples of before- and after-treatment cohorts based on the following regression:

$$
\mathrm{y}_{\mathrm{ijt}}=\mu_{\mathrm{j}}+\mathrm{x}_{\mathrm{ijt}} \beta+\mathrm{Z}_{\mathrm{jt}} \mathrm{d}_{\mathrm{t}}+{ }_{\text {.ijt }}
$$

where $y_{i j t}$ is the ith student outcome in school $j$ and year $t$; $x_{i j t}$ is a vector of student characteristics in school $\mathrm{j}$ and year $\mathrm{t} ; \mathrm{Z}_{\mathrm{jt}}$ is the treatment indicator, which equals 1 for district 9 students and $\mathrm{d}$ is the treatment effect. I will estimate equation using three samples, the two natural experiments samples and the full sample of district 9 and of GR. However, the before-and-after cross section data can also be used as a stacked panel data that permits regression analysis with control for primary-school fixed effects. This form of difference in differences (DID) estimation will also account for constant unobservables differences between the treatment and the control group. I therefore will estimate stacked models using the three years of cross-section data together. The treatment indicator $\mathrm{Z}$ is now defined as the interaction between a dummy for year 1994 and the indicator of district 9 as follows:

$$
\mathrm{y}_{\mathrm{ijt}}=\mu_{\mathrm{jt}}+\pi_{\mathrm{t}}+\beta\left(\mathrm{x}_{\mathrm{ijt}} \mathrm{d}_{\mathrm{t}}\right)+\delta .\left(\mathrm{Z}_{\mathrm{jt}} \mathrm{d}_{\mathrm{t}}\right)+\varepsilon_{\mathrm{ijt}},
$$

where $\pi_{\mathrm{t}}$ are year (i.e., 1992, 1993 and 1994) effects. The dependent variable, $\mathrm{y}_{\mathrm{ijt}}$, is the outcome of student $\mathrm{i}$ in school $\mathrm{j}$ in period t. In addition to providing a check on the precision of the 1992-1993-vs.1994 contrast in treatment effects, equation (2) may be seen as a framework for the control of omitted school effects that correlate with treatment status. The validity of this control, however, depends on the validity of an additive conditional mean function as a specification for potential outcomes in the absence of treatment. 


\section{Results: Graphical Presentation of Differences-in-Differences Estimates}

Figure 2 presents the estimated effect of the program and the respective 95 percent confidence intervals for each of the following outcomes: dropout rate, matriculation-certificate eligibility, average matriculation score, number of matriculation credits, number of matriculation credits in science subjects, and number of subjects at honors level. Each point on the graphs represents a point estimate obtained by estimating equation 2 with samples defined by the bandwidth. In the range 150-500 meters the bandwidth is changed by increments of 50 meters, between 500 and 2000 by 250 meters, between 2000 and 3000 by 500 meters and from 3,500 and beyond the sample include all observations.

The graphs connecting the point estimates and their respective confidence intervals show that in each of the samples the program had a significant impact on the following four (of the six) outcomes: the matriculation rate, average score, credits and number of subjects at honor level. There is evidence that the program also reduced the dropout rate but this effect is measured precisely only in bandwidth of 400 meters and beyond. The estimated effect on the number of credits in science subjects is also positive but it becomes significant only in bandwidths beyond 1,500 meters.

The graphs reveal a common pattern of declining point estimates as the bandwidth is gradually widened but from about 400 meters and beyond the point estimates stay relatively unchanged. In the next section I present more detailed results for the 200 and 250 meters samples as well as for the full sample.

\section{Results: Detailed Cross Section and Differences-in-Differences Estimates}

In this section I first discuss the results based on the full sample. Table 3, columns 1-3, presents the results for three cohorts: 1992 and 1993 which are pre-treatment and 1994, a cohort already exposed to the choice program. The table presents results for the six outcomes described in the data section and shown in Figure 2. For each outcome and year, the table presents the unconditional and conditional mean differences between treatment and control. The table also shows the absolute means of each outcome for the control group.

The estimates presented in the first two columns of Table 3 show that district 9 students had lower high-school outcomes than GR students before the program started. The outcome levels and treatmentcontrol differences were remarkably similar in both years. For example, the unconditional mean dropout rates in district 9 in 1992 (17.9 percent) and in 1993 (19.3 percent) were more than twice the corresponding rates in GR. The mean matriculation rates in GR in 1992 and 1993 (60 and 63 percent, respectively) exceeded those of district 9 by 40 percent. Similar differences were observed in the other outcomes presented in the table. However, controlling for students' characteristics reduces much of these baseline differences. The treatment-control conditional mean difference of the dropout rate in 1992, for example, is 4.7 percent as against a simple mean difference of 9.2 percent. The corresponding matriculation rate unconditional difference was -16.5 percent while the respective conditional difference 
is 1.3 percent. This pattern recurs in all six outcomes, suggesting that much of the observed outcome differences are explained by observed differences in characteristics.

Column 3 in Table 3 presents the results for the first cohort that was exposed to the program. Comparing the simple treatment-control mean differences and the conditional differences of the 1994 cohort with those of the two pre-program cohorts, reveals a large relative improvement in outcomes of students of district 9. The magnitude of the improvement implied by the comparison of the simple differences are very similar to those based on the conditional differences. The difference in differences estimates, based on using these cross sections, demonstrates best this important similarity and also provide a concise summary of these results. Column 4 presents DID estimates when all three cross sections are used and column 5 presents the estimates when only the 1993 and the 1994 cohorts are included. The results in both columns are very similar and therefore I discuss here only those presented in column 5. The DID estimates closely resemble the difference of simple mean differences and also the difference of conditional differences presented columns 2-3. They are significant for all outcomes except for the number of science units, for which the point estimates are positive but imprecise. For example, they suggest the program led to a 7-8 percentage point decline in the dropout rate and to a 7-8 percentage point increase in the matriculation rate. It is important to note again that these estimated effects are not sensitive at all to whether the regressions include student-level individual controls. This is probably due to the absorption by the school fixed effects of most variance among students in their background characteristics. Thus, the DID estimates support the interpretation of earlier results as causally related to treatment. ${ }^{14}$

To assess how sensitive are the results to the use of GR as a comparison group, I used instead the two adjacent large cities south of Tel Aviv that are also part of the Dan metropolitan area, Bat-Yam and Holon, as an alternative comparison group. Based on balancing tests for students' characteristics and outcomes I conclude that this comparison group looks much more similar to district 9 than GR. Yet, the evidence based on Bat-Yam and Holon as a comparison group and presented in Table A1 is remarkably similar to those presented in Table 3.

\section{The Results Based on the Regression Discontinuity-Natural Experiment Samples}

The main weakness of the foregoing results relates to pre-treatment imbalances between treatment and control in students' characteristics and outcomes. The before-and-after comparison and the control for primary-school fixed effects do take care of any unobserved constant differences between treatment and control. However, we cannot completely rule out the possibility of some treatment-control differential

\footnotetext{
${ }^{14}$ On average, 6 percent of students in district 9 and about 10 percent of those in GR enrolled in middle schools outside of their city of residence but I kept these students in the sample I used. The results based on a sample that excluded them are identical to those presented in Table3.
} 
trends in unobserved characteristics, even though the period analyzed is very short, just three years, and no changes were seen from 1992 to 1993 between the groups as well as no evidence of treatment-control outcome differences in time trends. The natural experiment samples are free from these concerns because the 1993 and 1994 treatment and control groups were shown to be identical in student characteristics. Below we will see that they are identical also in mean outcomes in 1993.

Table 3, columns 6-11 present cross section and differences in differences estimates from samples based on bandwidths of 200 and 250 meters. Columns 6-7 and 9-10 presents the cross section results of the 1993 and 1994 cohorts, for each sample respectively, and columns 8 and 11 presents the respective DID estimates. Columns 6 and 9 show that in 1993 there were zero or no systematic treatment-control differences in mean outcomes; the observed differences have different signs across outcomes and they are not statistically significant, especially after conditioning on covariates. This close resemblance in preprogram outcomes parallels the almost identical means of students' characteristics of the two groups shown in Table 2. However, the 1994 differences show an advantage for the treatment group that is statistically significant in some cases, especially in the 250 bandwidth sample. The respective DID estimates, which were already presented in Figure 2, also indicate positive program effects which are significant for four of the outcomes and in both samples. The effect on the dropout rate is negative and on the number of science units it is positive but these two effects are not precisely measured.

As seen already in Figure 2, the samples based on narrow bandwidths yield somewhat larger treatment estimates than those obtained from the full sample (column 5). One possible explanation for this pattern is treatment heterogeneity, perhaps due to different socio-economic background or other unobserved characteristics of those who resides near the Tel Aviv and GR border. This type of program effect heterogeneity is reflected in the local average treatment effects estimates based on the 200 or the 250 bandwidth samples while the estimates that the full sample yields are average treatment effects.

\section{Heterogeneous Treatment Effects}

The effect of school choice may vary in accordance with students' background characteristics. In particular, unrestricted access to better schools and a better match between pupils and schools may have a stronger effect on disadvantaged students. Table 4 presents the estimates for samples stratified first by fathers' education, column 1 for less than 12 years of schooling and column 2 for 12 or more. ${ }^{15}$ The estimates are generally precise and suggest that disadvantaged students benefited dramatically from the school-choice program, gaining a 7 percent decline in the dropout rate, a 6.2 percent increase in the matriculation rate, a 6 points increase in average score and a 1.5 credits increase. The effect on science credits and on number of honors subjects for the low-education group was also positive but not measured precisely enough. All these gains are very large relative to the respective counterfactual. Children with 
high parental education recorded smaller improvements. The choice program led to improvements in just two outcomes for this group: a 5 percent decline in the dropout rate, which may be considered a large change in view of the otherwise counterfactual rate and a 4-point gain in average score. This pattern was not sensitive to using alternative father's education cutoff of points such as 10 or 11 years of schooling.

The finding that disadvantage students benefit more than others from access to school choice is consistent with the evidence on the effect of school vouchers in the U.S. (Hoxby 2002; Peterson et al., 1998; Krueger and Zhu, 2004). ${ }^{16}$

Table 4 also shows results separately for males (Column 3) and females (Column 4). The results suggest that the program had some differential effects by gender. It led to a very sharp decline in the male dropout rate, almost 12 percentage points relative to the otherwise counterfactual rate, and a smaller decline in the girls' dropout rate, only 3.3 percentage points, although the counterfactual rate was also small. On the other hand, the matriculation gain was greater for girls than for boys (6.5 percent and 4.5 percent, respectively). In three of the remaining four outcomes, boys made much larger gains: average score (9 versus 4 points), matriculation units (2.6 versus 0.6$)$, and number of honors subjects (. 3 versus $0.1)$.

\section{Individual Effects: Opting Out Versus Staying in Neighborhood Schools}

The question of whether students who preferred opting out to schools in more affluent neighborhoods benefited more from the choice program is important for uncovering the sources of the benefit of TASCP. These students could have gained more because of better peers and better schools. Against this we should weight the gain from possible better student-school matches and from the enhanced competition faced by schools, both within district 9 and from out of district schools. The fact that students are not being bused or assigned anymore to schools against their may be improve student's motivation and their general well being. The individual contribution of each of these factors cannot be measured but the importance of the effect of opting out can be estimated. I turn next to assess whether the general equilibrium effects presented in the previous section reflect mainly the gain to students who opted out or is the gain from choice is equally shared by students who enrolled in schools in district 9 .

Simple OLS estimates of opting out status on outcomes are presented in Table 5. The table presents results for two alternative definitions of opting out: the first is to schools in districts 1-4 and the second is to schools in districts 1-8. ${ }^{17}$ They suggest that those who opted out to schools in districts 1-4 (or

\footnotetext{
${ }^{15}$ The results of using mothers' years of schooling instead of fathers', or of using both, were very similar.

${ }^{16}$ Several studies have also shown that the outcomes of disadvantaged students are more responsive to changes in school resources (Angrist and Lavy, 1999; Krueger, 1999; Hoxby, 2000b; Jepsen and Rivkin, 2002).

${ }^{17}$ Although the TASCP from allowed out of district choice only among schools in districts 1-4, some of district 9 students attended from first grade one of the two charter schools located in districts 7 and 8 . Although very few of district's 9 students were enrolled in these two schools, showing the OLS results based on this more general definition of opting out is called for.
} 
in districts 1-8) had on average significantly better outcomes. For example, they had a lower dropout rate (0.093 versus 0.142 for those who chose to remain in district 9 ), higher matriculation rate (60.6 versus 47.9), higher average score ( 72.6 versus 63.4$)$, more science credits (2.1 versus 1.3 ) and more honor level subjects (1.93 versus 1.64). However, these differences may simply reflect the endogenous sorting discussed in Section I. The lower panel in Table 5 shows indeed that controlling for students' background characteristics lowers dramatically these gaps.

To uncover the causal effect of opting out I adopt in this section an instrumental-variable strategy, using three different instruments - the distance to the nearest school in the choice set, an indicator of the proximity of students to public transportation and an indicator of whether a student has siblings of middleschool age who are assigned for busing to schools outside of district 9. Below I explain the rational and credibility in using these instruments as exogenous sources of variation in students' propensity to opt out for estimating the causal effect of opting out on long term high school outcomes.

\section{Proximity to Public Transportation and Distance to Schools as Instruments for Opting Out}

Empirical evidence (for example in Hastings, Kane and Staiger 2005) suggests that the distance to school and availability and cost of transportation are important determinants of school choice Therefore, a potential instrument for the effect of opting out is the distance to schools in the choice set. However, this distance is potentially endogenous since family location may respond to the choice program. But in our case this concern is not relevant since students had to make their choice within a month from the announcement of the program, leaving practically no time to respond in terms of residential location.

There are two reasons in our case to prefer the distance to nearest schools in the district as the relevant instrument. First, it could be that the out of district schools included in the choice set of students were not free of consideration that would create a spurious correlation between the distance to these schools and potential outcomes. Second, one of the three district 9 schools was always the nearest to each of the students. Actually, all these secondary schools were clustered in one campus. To avoid the potential endogeneity in the distance to out of district schools and to exploit the idea that the distance to the nearest school is the most important factor in school choice, I chose the distance from home to the high schools campus in the district as the relevant measure of proximity to school.

The mean distance to the nearest school is $1.75 \mathrm{~km}$, from a minimum of half a $\mathrm{km}$ to a maximum $4.5 \mathrm{~km}$. Column 2 in Table 6 presents balancing tests for this potential instrument with observable students' characteristics. The tests are based on regressions of students' characteristics on the instrument. The distance to school is positively correlated with father and mother schooling but in both cases the standard errors are high and yield low t-statistics. Some more precise imbalances are seen for the other characteristics but they are not systematic in terms of the direction of the differences. For example, distance to school is positively correlated with number of siblings but negatively correlated with the Asia- 
Africa ethnic group, a pattern not consistent with the usually observed strong positive correlation between family size and Asia-Africa ethnic origin. A similar contradiction arises by comparing the sign of the correlation between distance to school and number of siblings and the correlation of distance to school with mother schooling. These conflicting patterns of correlations suggest perhaps that the imbalances in some of the variables in column 2 are random. This interpretation of the correlation of the distance to the nearest school with some of the observed student's characteristics will gain further support by the evidence shown below that the estimated effect of the distance to school in the first stage and the reduce form equations are not sensitive at all to the inclusion of these background characteristics as controls.

Another potential instrument that can be used arises from the fact that the program provided convenient and free transportation for opting out students but not to others. Students who attended a school in district 9 had to use own or public transportation. Since public buses run only on main streets, students who live near a main public bus route enjoyed, relative to other students, more convenient access to neighborhood schools which may be reflected in their higher propensity to attend local schools. If residing near a bus route is not correlated with observed or unobserved potential outcomes, it could provide potentially useful exogenous variation in opting out. To generate an instrument based on this idea, I coded an indicator (Instrument 2) based on whether the student resides on a public bus route versus otherwise. In the 1993 and the 1994 samples, 119 and 149 students, respectively, met this criterion. Table 6 , columns 4 and 6 , presents balancing tests for the differences in means of the samples created by this instrument in 1993 and 1994, respectively. The tests suggest that students who reside on a public bus route are almost identical in their observed characteristics to students who reside off bus routes. In terms of parental schooling, number of siblings, gender, and immigration status, the two groups are identical: none of the 16 estimates of is statistically different from zero. These balancing tests suggest that this proposed alternative instrument is orthogonal to students' observable characteristics and so, perhaps, to their unobservable characteristics as well. Against the perfect balancing of this instrument, I note its shortcoming, a relatively small number of students that their opting out behavior might be manipulated by the instrument.

\section{Having an Older Sibling assigned for busing as an Instrument for Opting Out}

Students who had older siblings (in $8^{\text {th }}$ or $9^{\text {th }}$ grade) whom according to their primary school had to attend out of district secondary schools may have a higher propensity to opt out due to convenience, safety, and considerations of similar nature. ${ }^{18}$ Thus, an instrument can be defined as an interaction term between two indicators: the first is whether a student has an older sibling in middle school age and the second is whether that sibling is in the busing program (regardless if he actually is or is not being bused). By defining the instrument this way, I minimize the possibility of it being correlated with (endogenous) 
choice because students in previous cohorts that were included in the forced busing program were bused only until the end of ninth grade, after which they could transfer to any other high school in the city. Note that these two indicators that form the instrument should be added as controls for their main effect in the first-stage and reduced-form equations.

Column 7 in Table 6 presents the descriptive statistics for students for which this instrument is equal to zero and column 8 presents the respective balancing tests. In 1994, seventy-two students met both criteria and the estimates in the table suggest that their observable characteristics are not significantly different from the rest of district 9 students that year. The two samples are almost perfectly balanced in respect to most covariates, particularly the almost identical means of father and mother schooling, the number of siblings in the family and the proportion of immigrants. ${ }^{19}$

\section{First Stage, Reduced Form and 2SLS Estimates}

Table 7 presents the first-stage, reduced-form and 2SLS estimates that are based on these three instruments. I first present result of using each of them separately and then results obtained by using them jointly. The first-stage dependent variable is an indicator of opting out of district $9 .{ }^{20} \mathrm{I}$ used two specifications, one without any controls included and a second that included as controls the student background characteristics and also few primary school characteristics (average socio-economic index, the average test score and the average passing rate in a reading test that all district 9 students took while in sixth grade).

The first and second rows in Table 7 present the first-stage and reduced-form estimated equations using the first instrument, without and with controls included, respectively. The distance to school has a positive and highly significant effect on opting out; For example, increasing the distance to the district's schools campus by one kilometer increases the probability of opting to out by 25 percent. When the controls are omitted from the first stage this estimate is 23 percent, reflecting that the instrument is not correlated with the observable characteristics, and therefore, perhaps also not correlated with confounding unobservables. The reduced-form effects are presented in columns 2-7. The estimates using the distance instrument are not statistically different from zero for all outcomes except for science credits in the specification that included the controls. In all cases the t-statistics where one or lower.

The $3^{\text {rd }}-4^{\text {th }}$ rows in Table 7 present the first-stage and reduced-form estimated equations using the second instrument (an indicator of access to a public bus). The first-stage estimate shows that residing on a public bus route also has a significant effect on opting out; it reduces the probability of opting out by

\footnotetext{
${ }^{18}$ The choice program applied only to the incoming $7^{\text {th }}$ graders. Older cohorts continued with zoning and busing.

${ }^{19}$ Due to data limitations in 1993, I could match students only to siblings who were in seventh or eighth grade in 1994 and not to those who were in ninth grade. This makes the 1993 sample much smaller but it leads to similar results, namely that the two samples are also very similar for the cohort of $7^{\text {th }}$ graders that preceded the program.
} 
23.4 percent when no controls are included and by 19.1 percent when the controls are added. Again, the similar first stage estimates from the two specifications is a result of the perfect balancing of the instrument in terms of the treatment-control differences. ${ }^{21}$ The reduced-form effect of this instrument on the drop out rate is positive and on all the bagrut outcomes is negative, but the six estimates are not statistically different from zero in each of the two specifications. The most precise estimates are the effect on the dropout rate (with t-statistics of 1.2) and on bagrut credits (t-statistics of 1.3).

Obtaining no reduced form effects based both on the first and the second instrument is somewhat reassuring about the quality of the identification of the effect of opting out. The correlation coefficient between the two instruments is relatively low, -0.17 .

The $5^{\text {th }}-6^{\text {th }}$ rows in Table 7 presents the estimates using the third instrument (based on having older siblings that are still eligible for busing). This instrument has a large and significant positive effect on opting out status. Students with siblings who are at secondary schools and are supposed to be bused to schools outside district 9 have a 58 percent higher probability of opting out. ${ }^{22}$ This is a stronger effect than that of the second instrument but it manipulates the behavior of fewer students. The reduced-form estimates of this instrument are positive in all the outcomes but four of them are practically zero and the other two (science credits and honor level subjects) are statistically significant.

The three rows of panel B in Table 7 present the 2SLS estimates that correspond, respectively, to each set of the first stage and reduced form equations. Overall the 2SLS estimates, similarly to the reduce form estimates, suggest that regardless of which of the three instrument is used the program did not affect students differentially by opting out status.

I also experimented with using the three instruments simultaneously which can be useful if the interest is to test the hypothesis of zero effect of opting out since it can lead to more precise estimates. The results are presented in Table 8. Column 1 presents the first stage estimates, three from an equation without controls and three from an equation with controls included. Each of the rows in panel A presents the reduced form estimated for one of the instruments. Focusing first on the first stage estimates, we can note that they are not sensitive to adding controls to the specification and therefore I discuss here only the results with controls included. Comparing the first stage estimates in Table 8 to the respective estimates presented in Table 7 suggests the effect of the two first instruments (distance to school and access to a public bus) fall in size when all three instruments are used jointly; especially the coefficient of the distance to school is almost halved, from 0.248 to 0.135 . These changes reflect the correlations between

\footnotetext{
${ }^{20}$ Defining opting out as attending schools in districts 1-4 or just in the city of Tel Aviv did not change the result presented in the paper.

${ }^{21}$ If Opting-out was defined as attending a school in districts 1-4, the effect of the instruments is slightly larger, 0.23. I also tried a variation on the definition of the instrument, one that extends the indicator to include also students who reside on or near a public bus route. The first-stage effect of this instrument is slightly weaker.

${ }^{22} \mathrm{We}$ should also note that over two thirds of the student who opted out chose the same middle school that their sibling attended.
} 
the three instruments ( 0.19 between instruments one and three, -0.17 between instruments two and three). The effect of the third instrument is almost unchanged: it is 0.576 when used alone and 0.533 when used jointly with the other two instruments.

The 2SLS estimates resulting from the first stage when all three instruments are used simultaneously confirm what could have been expected given the 2SLS estimates shown in the first three rows of panel B. The signs of the point estimates (except for dropping out) indicate that opting out has an adverse effect on student's high school outcomes but no one of the six estimates is measured precisely enough to reject the hypothesis that they are not different from zero. Three of the t-statistics are about one and the three others are much lower than one.

These results are in sharp contrast to the simple outcome mean differences between students who opted out and students who did not (based on OLS estimates presented in Table 5). The instrumentalvariables estimates in Table 7-8 suggest that the OLS estimates in Table 5 reflect only sorting by ability to out-of-neighborhood schools. I should note however, that most of the IV estimates and their standard errors do not allow rejecting the naïve simple positive outcomes differences between those who opted out and those who did not (the confidence intervals of the IV estimates include the point estimates of these naïve contrasts). However, once controls are added to the OLS estimates, they are also not significantly different from zero.

The result that students who opted out did not do better than others are very similar to the findings of Cullen, Jacob, and Levitt $(2003,2005)$ that Chicago students who won a lottery to attend a public school of their choice did not improve their achievements. However, there is an important distinction between the Chicago and the Tel Aviv programs since in the latter students who did not opt out still could chose their preferred school among the three schools in their district while in the Chicago program the default of not applying to the lottery was attending the neighborhood school. Another related distinction is the positive general effect of TASCP estimated in this paper but not studied for the Chicago program.

\section{Discussion and Interpretation of the Results}

The significant positive general equilibrium effect of 'compulsory' choice (versus no choice that preceded the program) and the lack of any discerned effect by opting out status suggest that the option of choice itself and the effect of competition among schools may be key to understanding the sources of the benefits from the TASCP. Choice may have had an effect on outcomes by improving the matching between students and schools, eliminating the 'cost' of busing kids against their will or of assigning students to undesired schools, and perhaps leading to higher student intrinsic motivation and less unwanted travel time. The patterns of choice by the first cohort enrolled in the program provide interesting insights that suggest that better matching and perhaps enhanced intrinsic motivation are key channels for the effects of the choice program. Almost two thirds (62\%) of district 9's students chose a 
different school from the one they would have had to attend if choice was not allowed. Among those who otherwise would have been bused to a Northern school this rate is slightly lower, 59 percent, and more than half of them chose an out of district school. The respective rate among those who otherwise would have had to attend a school within district 9 was 65 percent.

The following contrast is even more compelling about the effect of the program on the pattern of actual choice: among the students that otherwise would have been bused to the North of the city and eventually chose to attend an out of district school, 40 percent chose a school that was different from the one they would have been bused to. Similarly, among the students that otherwise would have been assigned to district 9 and eventually chose to attend a district 9 school, 35 percent chose a school that was different from the one they would have to attend otherwise.

This evidence implies large disparities between the preferred school chosen by students and the school they would have had to attend otherwise. It suggests that allowing school choice improved the pupil-school match for two thirds of the students. More evidence and insights about the importance of these mechanisms is provided by Shapira and Hieman $(1998,2002)$ who studied the individual (students and parents), pedagogical (teachers and schools) and organizational (schools and education districts) changes that followed the TASCP. For example, they noted that enrollment based on free choice led to improved student's intrinsic motivation, self confidence and satisfaction from school $^{23}$; that schools developed an innovative dialogue with their students aiming to better understand their needs and also involving them in school decision making; that schools reacted to the freedom given to them to develop special educational programs to attract students, for example, by developing new programs in communications and bio-technology, special curricula for high ability students, including early enrollment in college while still in high school and also special programs for under-achieving students. The authors emphasize that all these changes have improved the match between students' cognitive ability or preferences and what schools had to offer.

Another potential mechanism is the competition among schools, between and within school districts that may have improved their productivity. The main threat faced by schools under competition was declining enrollment which could lead to the closure of the school and loss of jobs for all school staff. Indeed one the high school in district 9 was closed in 2000 due to sharp decline in enrollment. Shapira and Hieman (2002) emphasize that the uncertainty about future enrollment created a sense of

\footnotetext{
${ }^{23}$ From a survey on student attitudes and behaviors, Hieman Shapira (1998) report high rates of students' satisfaction from school, from the learning and social environment, from the support and trust from their teachers. They also found evidence of optimism about their future and self esteem. Interestingly, no differences in any of these dimensions were found between students who opted out and those who remained in neighborhood schools. As a support to these findings, Hieman and Shapira add that following: in the context of a 1996 Supreme Court appeal against the TASCP, parents' school boards of all primary schools in district 9 asked the court to allow them to join as responders to the appeal. In their deposition the school parental boards presented a detailed description of the positive changes among students, parents and schools induced by the program.
} 
permanent tension in schools that stimulated educational renewal and quality improvement. They also suggest that the competitive environment between schools was enhanced by the increased educational awareness and involvement of parents at home, in the school and in the community. For example, parents expected and demanded more from schools but were also ready to partner and invest more in their children's education. Another factor emphasized by these authors is monitoring, testing and accountability measures that were part of TASCP.

\section{Conclusions}

This paper examined the effect of a program that changed the rules of students' enrollment in public high schools from zoning and forced busing to unrestricted school choice. The empirical results contribute to the debate over whether breaking the link between neighborhood and schooling improves public schools' performance through induced competition, improved matching of students and schools, and elimination of distortions occasioned by forced busing. The first part of the paper focused on the general equilibrium effect of choice in public schools. The results suggest that school choice led to large improvements in attainment and in the quality of the curriculum of study, as reflected in a reduced dropout rate, a higher matriculation rate, and a higher mean score on the matriculation exams. ${ }^{24}$ The improvements are also noticeable in quality measures of the program of studies as credits in science subjects and the mean number of subjects studied at the honors (most advanced) level. The effects are greater among disadvantaged students and vary by gender for various outcomes. The results are robust to different comparison groups used for identification. The positive effect of school choice in TASCP can be contrasted with Hoxby (2000), who reports a substantial positive effect of metropolitan-level Tiebout choice options on student test scores and negative effects on spending, to Bayer and McMillan (2005) who find strong performance responses of schools to competitiveness in their local environment and to Rothstein (2004a, 2004b) who finds little effect of choice on students' academic achievements and no evidence that choice improves average school effectiveness.

By using an instrumental-variable estimation strategy, I then estimate the differential individual effects of treatment by opting-out status. Unlike the OLS results, which suggest that students who opted out had much better outcomes than students who did not, the instrumental-variables estimates show no differential effect of the choice program by opting out status. One of the instruments I used mimics a quasi-experiment in which students are randomly allocated older siblings who were assigned for busing to secondary schools outside their district, and two other instruments mimics a quasi-experiment in which

24 The improvement in the matriculation rate implies significant economic gains. Angrist and Lavy (2004), for example, estimated the relationship between matriculation status and log monthly wages in a sample of men aged 30-59 in the 1995 Israeli census. The rate of return on a year of schooling was estimated at about 8.3 percent while holders of matriculation certificates earn a further 24 percent. The returns on matriculation partly reflect the 
students are either randomly assigned good or bad access to public transportation and a distance to the high schools campus in their school districts. In all three cases no differences in long term high school outcomes were found between students who opted out to higher achieving high schools and those who preferred enrollment in own neighborhood high schools. The lack of any differential effect of opting out status resembles the no effect of voucher programs that allowed students to opt to out of districts schools (For example, Cullen, Jacob and Levitt, 2003 and 2005). However, the important distinction between the two sets of partial equilibrium results is that in this paper the lack of any benefit from opting out is against a positive and significant general equilibrium effect from school choice.

In many respects, these findings can be of general interest beyond the local Israeli context. The Tel Aviv choice program resembles many recent programs in US school districts where free choice replaces, under court order, zoning and forced busing. The lessons learned from an analysis of the individual and general equilibrium effect of choice are also increasingly relevant to European and some developing countries who implemented system wide and more comprehensive choice programs.

increased likelihood of higher education. Even in a sample limited to those with exactly twelve years of schooling, however, certificate holders earn 13 percent more. 


\section{References:}

Ahlin, Asa (2003): "Does School Competition Matter? Effects of a Large-Scale Choice Reform on Student Performance." Working paper, Uppsala University.

Angrist, J. E., Bettinger, E., Bloom, E., King, Kremer, M., "Vouchers for Private Schooling in Colombia: Evidence from a Randomized Natural Experiment," American Economic Review, December 2002.

Angrist, J., Bettinger, E., and Kremer, M., "Long-Term Consequences of Secondary School Vouchers: Evidence from Administrative Records in Colombia," NBER WP 10713, August 2004.

Angrist, Joshua D., and Lavy, Victor. "The Effect of High School Matriculation Awards: Evidence from Randomized Trials," October 2004.

Bayer, Patrick. And Robert McMillan. "Choice and Competition in Local Education Markets." NBER Working Paper 11802, November 2005.

Black, Sandra, "Do Better Schools Matter? Parental Valuation of Elementary Education," Quarterly Journal of Economics, 114(2), May 1999, 577-99.

Bradley, Steve, Geraint Johnes and Jim Millington (2001): "The Effect of Competition on the Efficiency of Secondary Schools in England", European Journal of Operational Research, 135: 545-568.

Chang-Tai Hsieh and Miguel Urquiola, 2003. "When Schools Compete, How Do They Compete? An Assessment of Chile's Nationwide School Voucher Program," NBER Working Papers 10008.

Clark Damon, "Politics, Markets and Schools: Quasi-Experimental Estimates of the Impact of Autonomy and Competition from a Truly Revolutionary UK Reform" Job Market Paper, Jan. 2005.

Cullen, J. B., Jacob, B.A., and Levitt, S.D., "The Impact of School Choice on Student Outcomes: An Analysis of the Chicago Public Schools," Journal of Public Economics, 2005. 89(5-6): 729-760.

Cullen, J. B., Jacob, B.A., and Levitt, S.D., "The Effect of School Choice on Student Outcomes: Evidence from Randomized Lotteries," NBER Working Paper 10133, November 2003.

Fiske Edward and Helen F. Ladd, When Schools Compete: A Cautionary Tale, Brookings Institution Press, 2000.

Gibbons, Steve, Steve Machin and Olmo Silva (2005): Competition, Choice and Primary School Performance. Working paper CEP/LSE.

Gurion, Jonathan, "Desegregation and Black Dropout Rates," December 2004, American Economic Review.

Hastings S. Justine, Thomas J. Kane and Douglas O. Staiger, "Parental Preferences and School Competition: Evidence from a Public School Choice Program”, NBER Working Paper 11805, December 2005.

Heiman. P., and R. Shapira, "Restructureing the Tradeoff in an Education System: Choice and Autonomy The Tel Aviv Vision.” Mimeo, School of Education, Tel Aviv University, 1998 (in Hebrew).

Heiman. P., and R. Shapira, "Parental Choice in Autonomous schools as a Stategy of Recstructuring Schooling Systems - The Case of Tel Aviv." Mimeo, Tel Aviv University, 2002 (in Hebrew).

Hoxby, Caroline M., "Does Competition among Public Schools Benefit Students and Taxpayers?" American Economic Review, 2000: 90, 1209-1238.

Hoxby, Caroline M., "School Choice and School Productivity (Or Could School Choice Be a Tide That Lifts all Boats?)," April 2002, NBER WP8873.

Hoxby, Caroline M., and Jonah Rockoff, "The Impact of Charter Schools on Student Achievement," Draft, November 2004.

Hoxby, Caroline M., "Competition among Public Schools: A Reply to Rothstein (2004)," NBER WP, 11216.

Krueger, Alan, and Zhu, Pei, "Another Look at the New York City School Voucher Experiment," American Behavioral Scientist, vol. 47, no. 5, January 2004.

Lankford, R. H., Lee, E. S., et al. "An Empirical Analysis of Elementary and Secondary School Choice," Journal of Urban Economics, 1995: 38, 236-251.

Levy. A., K. Levy and M. Libman., "An Evaluation of the Tel Aviv School Choice Program: the First Year." Tel Aviv University, Evaluation Unit, School of Education, 1996 (in Hebrew). 
Levy. A., K. Levy and M. Libman., "An Evaluation of the Tel Aviv School Choice Program: the Second Year." Tel Aviv University, Evaluation Unit, School of Education, 1997 (in Hebrew).

Mayer, Daniel P., Peterson, Paul E., Myers, David E., Clark Tuttle, Christina, and Howell, William G., "School Choice in New York City after Three Years: An Evaluation of the School Choice Scholarships Program," Washington, DC: Mathematica, 2002.

Obrien, D. M., and Murdoch, J. C., School Choice in a Large Texas School District, American Education Finance Association Annual Meeting, 2000, Austin, Texas.

Peterson, P., Myers, E., D., and Howell, William G.. "An Evaluation of the New York City School Choice Scholarship Program: The First Year," Cambridge, MA, 1998, Mathematica.

Rothstein, Jesse M., "Does Competition among Public Schools Benefit Students and Taxpayers? Comment," Mimeo, February 2004.

Rothstein, Jesse M., "Good Principals or Good Peers? Parental Valuation of School Characteristics, Tiebout Equilibrium, and the Incentive Effects of Competition among Jurisdictions," Working Paper No. 10, Princeton University, Education Research Section, December 2004.

Rouse, C. E., "Private School Vouchers and Student Achievement: an Evaluation of the Milwaukee Parental Choice Program," Quarterly Journal of Economics, 1998: 118, 553-602.

Sandstrom, F. Mikael and Fredrik Berstrom (2002): School Vouchers in Practice: Competition Won't Hurt You!". The Research Institute of Industrial Economics.

Shapira, R., and Cookson, Jr., P. W., Introduction in Shapira, R., and Cookson, Jr., P. W., Autonomy and Choice in Context: An International Perspective, 1997, Elsevier Science, Ltd., UK.

Tel Aviv Educational Authority, An Organizational and Educational Program to Develop The Post Primary Schooling In Tel Aviv, 1994 (in Hebrew).

Tel Aviv Educational Authority, Response to a Petition to the High Court of Justice Against the Choice Program, 1996 (in Hebrew).

Tel Aviv Educational Authority, Evaluation Report of the Choice Program, 1999 (in Hebrew).

Tel Aviv Educational Authority, Tracking Student Mobility In Tel Aviv, 2001(in Hebrew). 
Figure 1: Balancing tests of students' characteristics for treatment-control samples, by distance in meters from the municipal border (dotted lines on either side of the treatment-control difference curves represent $95 \%$ confidence intervals).

Father's years of schooling
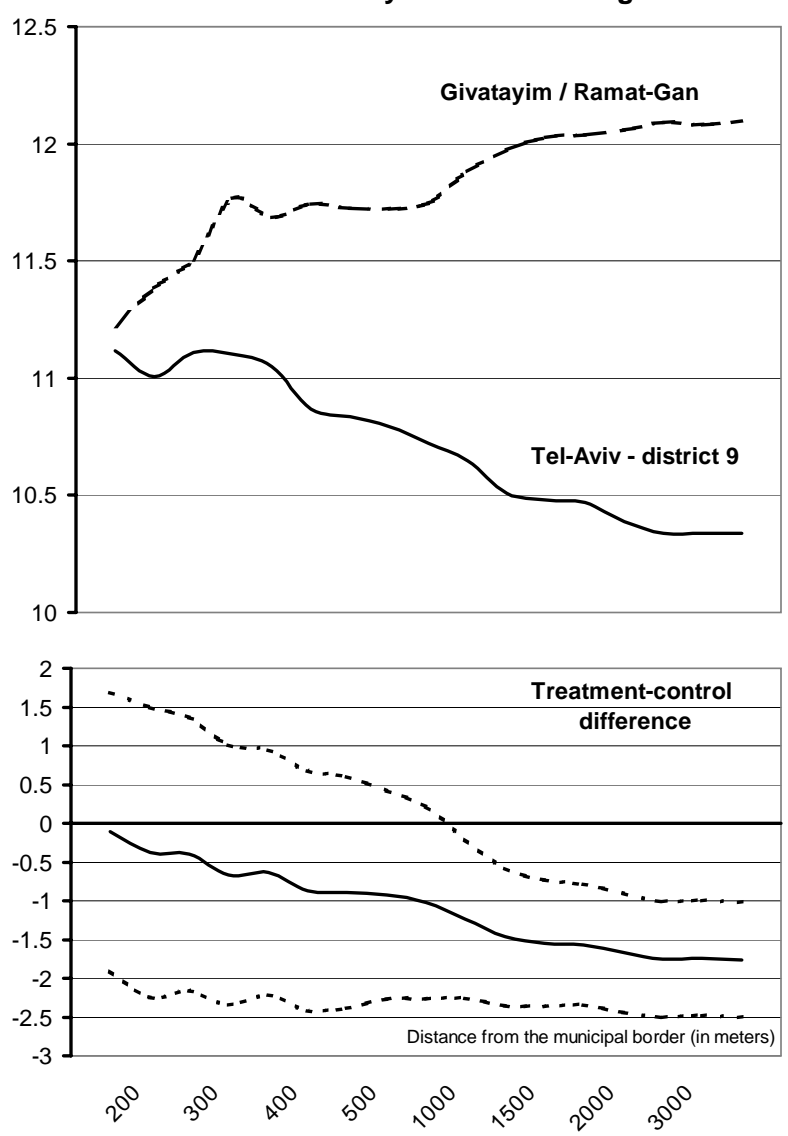

Number of siblings
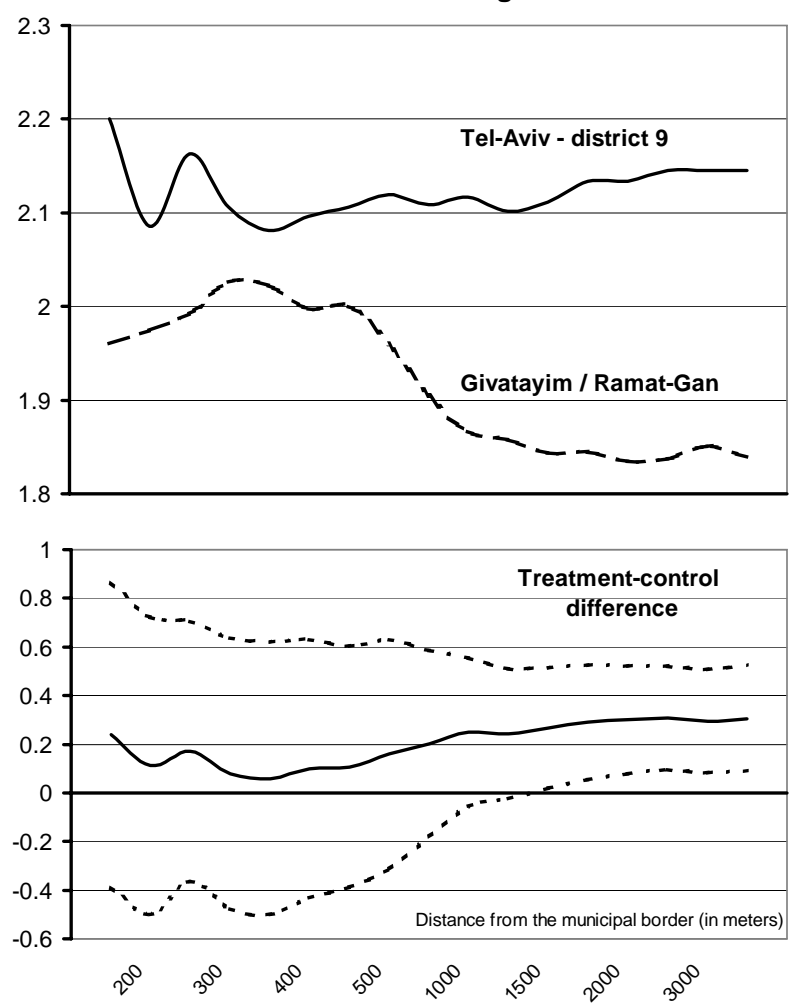

Mother's years of schooling
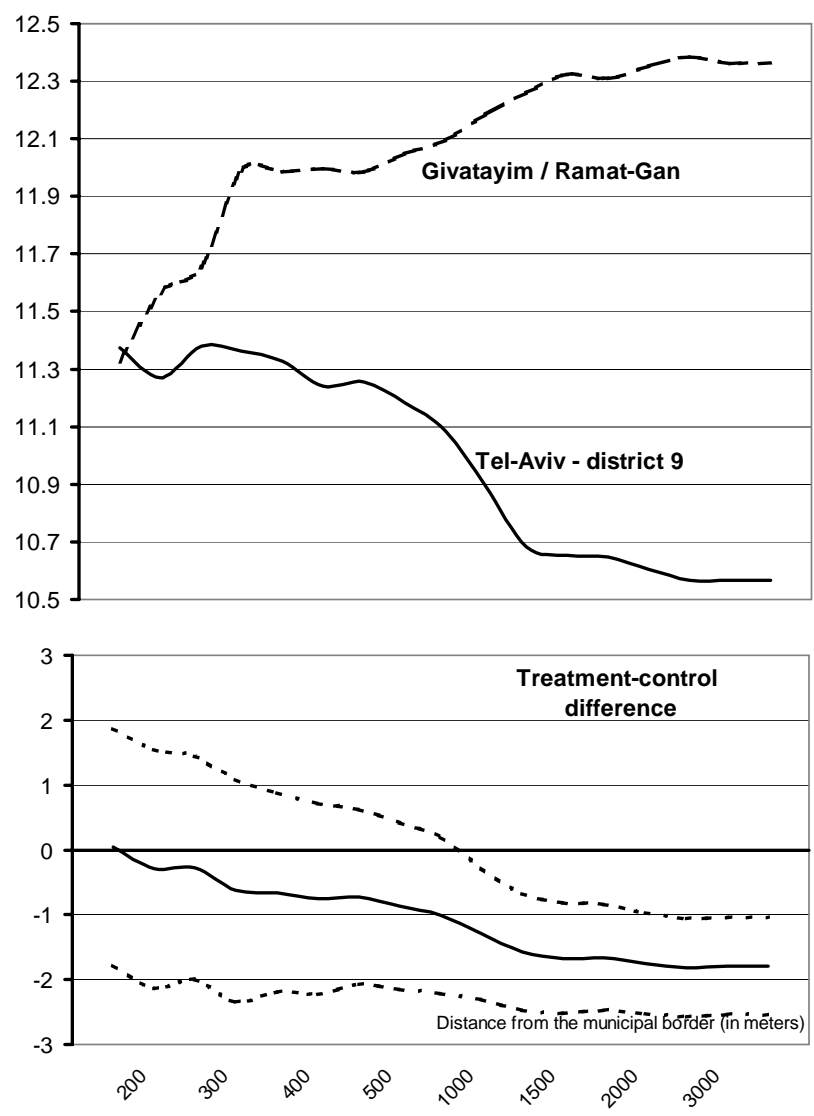

Proportion of ethnic origin from Israel
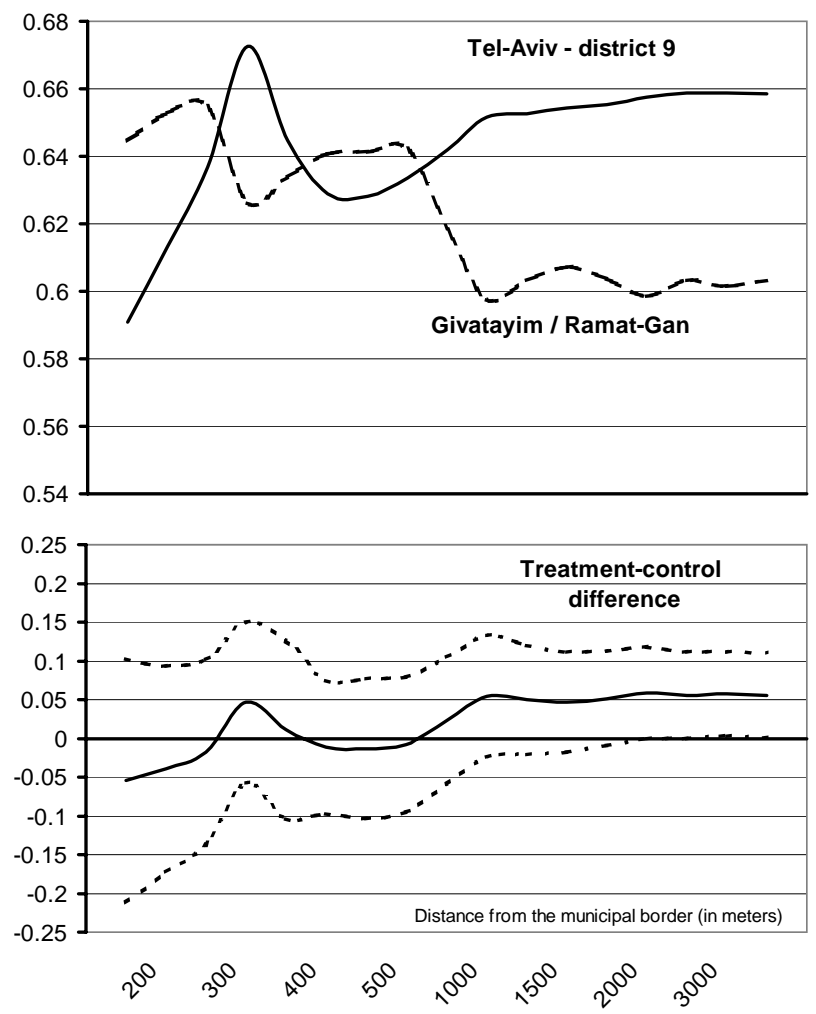
Figure 2: Differences-in-differences Program effect estimates for samples defined by distance in meters from the municipal border (dotted lines on either side of the treatment-control difference curves represent $95 \%$ confidence intervals).

Drop-out rate

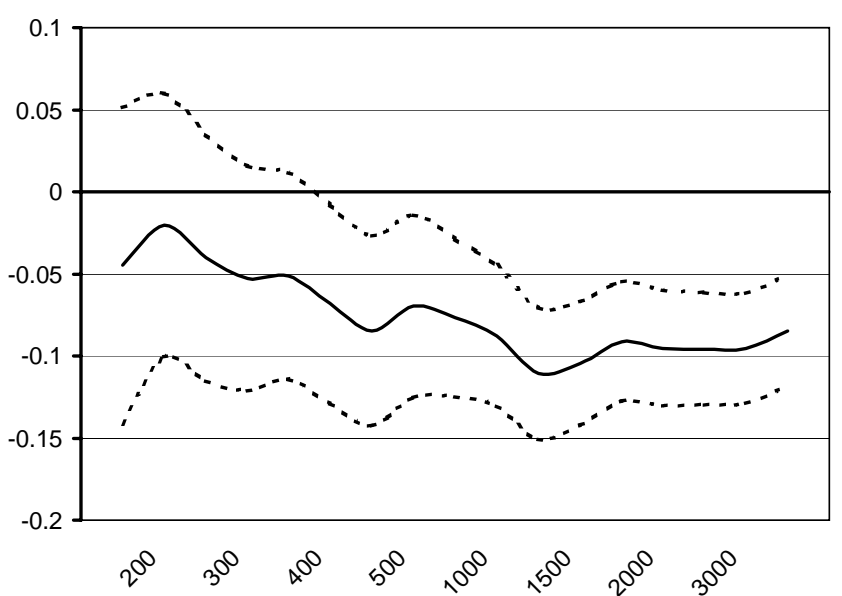

Matriculation credit units

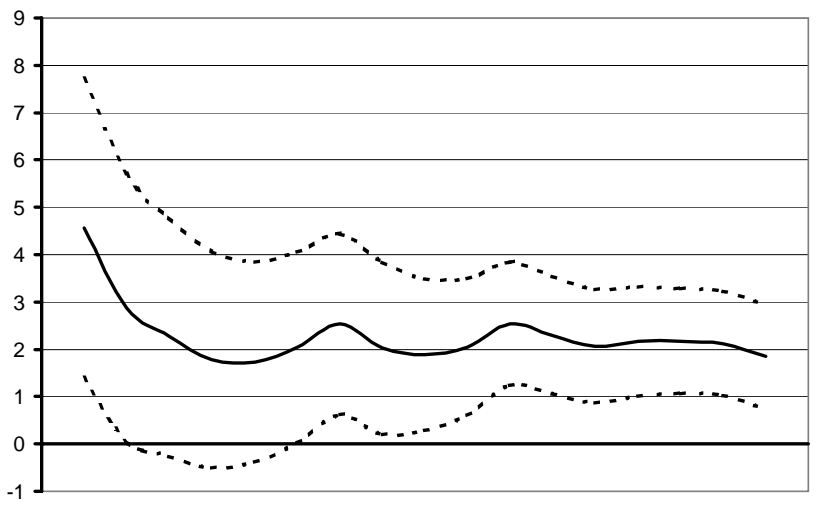

$\vartheta^{\circ} \quad 3^{\circ} \quad 2^{\circ} \quad 5^{\circ} \quad 2^{\circ} \quad 5^{\circ} \quad 2^{\circ} \quad 3^{\circ}$
Matriculation rate

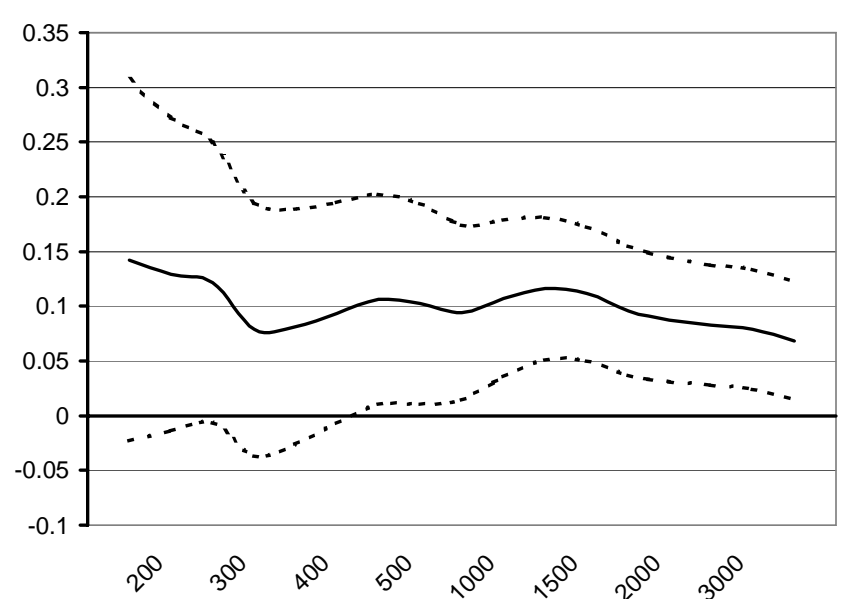

Matriculation credit units in science subjects

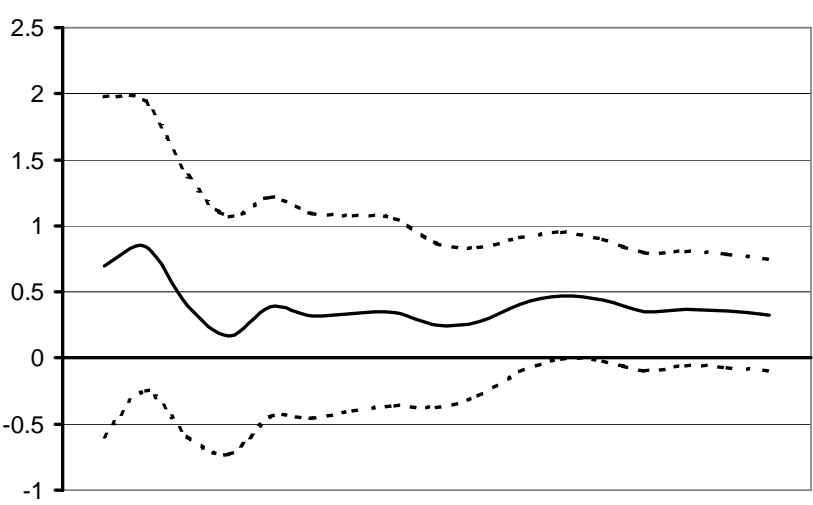

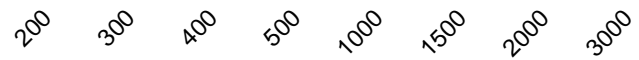

Average test scores

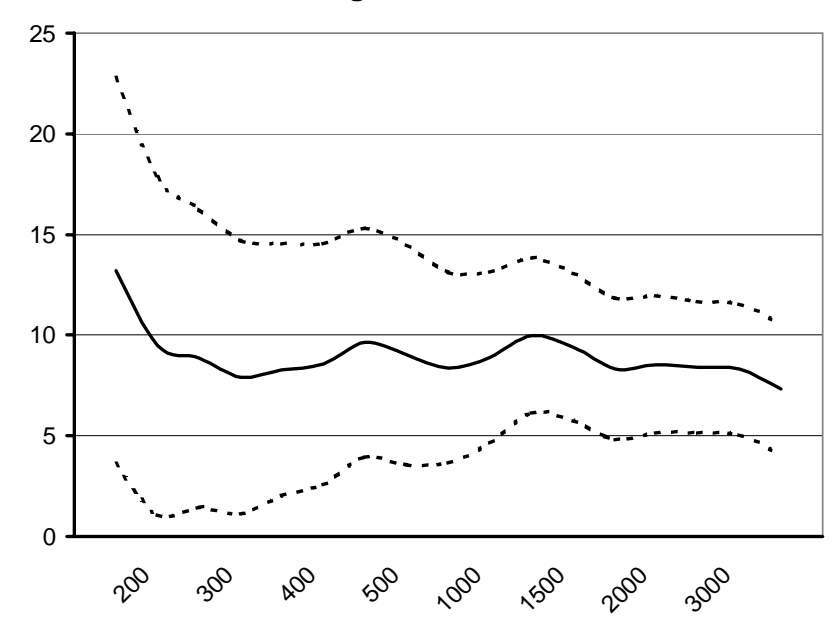

Number of subjects studied at advance level

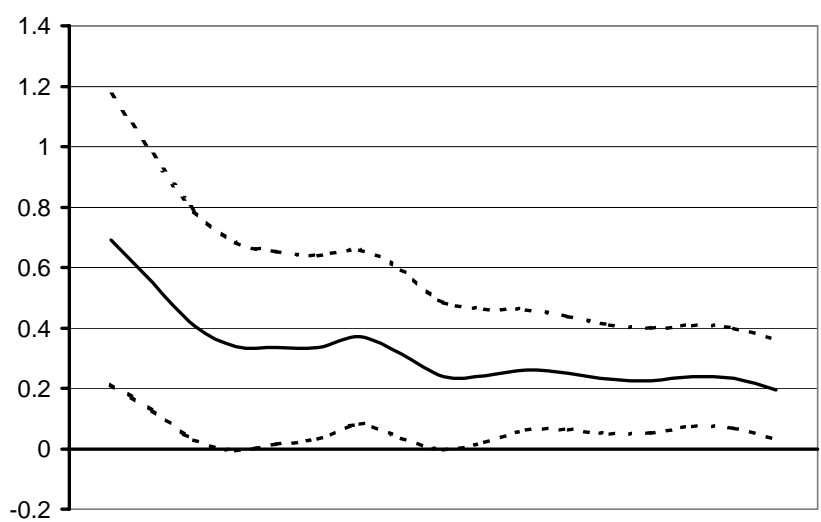

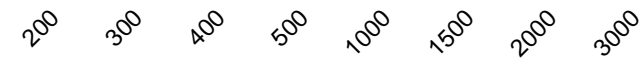


Table 1 - Student Mean Characteristics and Outcomes by Location District 9, Tel Aviv, Ramat Gan, and Giv`ataim, 1993

\begin{tabular}{|c|c|c|c|c|c|}
\hline & $\begin{array}{c}\text { Tel Aviv } \\
(1)\end{array}$ & $\begin{array}{c}\text { District } 9 \\
(2)\end{array}$ & $\begin{array}{c}\text { Giv`ataim and } \\
\text { Ramat Gan } \\
\text { (3) }\end{array}$ & $\begin{array}{c}\text { t-value: } \\
\text { (2) vs (1) } \\
(4)\end{array}$ & $\begin{array}{c}\text { t-value: } \\
\text { (2) vs (3) } \\
\text { (5) }\end{array}$ \\
\hline \multicolumn{6}{|l|}{ Students' characteristics: } \\
\hline Father's years of schooling & 12.319 & 10.752 & 11.931 & -2.41 & -3.47 \\
\hline Mother's years of schooling & 12.325 & 10.988 & 11.998 & -2.22 & -3.27 \\
\hline Number of siblings & 2.056 & 2.258 & 2.024 & 2.10 & 3.05 \\
\hline Gender (male=1) & 0.508 & 0.525 & 0.521 & 1.40 & 0.22 \\
\hline Immigration status & 0.080 & 0.088 & 0.076 & 0.51 & 0.53 \\
\hline Country of origin - Israel & 0.623 & 0.631 & 0.609 & 0.29 & 0.77 \\
\hline Country of origin - Asia/Africa & 0.177 & 0.222 & 0.185 & 1.88 & 1.85 \\
\hline Country of origin - Europe/America & 0.099 & 0.044 & 0.098 & -2.84 & -4.04 \\
\hline \multicolumn{6}{|l|}{ Students' outcomes: } \\
\hline Drop-out & 0.154 & 0.193 & 0.086 & 1.11 & 4.87 \\
\hline Eligibile for Bagrut & 0.562 & 0.446 & 0.634 & -1.67 & -4.33 \\
\hline Average score & 69.655 & 60.055 & 76.823 & -1.83 & -5.75 \\
\hline Number of Bagrut credits & 17.907 & 15.794 & 20.753 & -1.42 & -5.14 \\
\hline Number of science credits & 2.558 & 1.496 & 3.012 & -2.13 & -5.78 \\
\hline Number of advanced-level subjects & 1.951 & 1.550 & 2.376 & -1.73 & -5.72 \\
\hline Number of students & 2,848 & 827 & 1,909 & 3,675 & 2,736 \\
\hline
\end{tabular}

Note: The samples includes only students in secular state schools. The Jewish religious and Arab schools are excluded. The Tel Aviv sample includes District 9 students. 
Table 2 - Descriptive Statistics and Balancing Tests

\begin{tabular}{|c|c|c|c|c|c|c|c|}
\hline \multirow[b]{2}{*}{ Dependent variable } & \multicolumn{2}{|c|}{$\begin{array}{l}\text { Natural experiment } \\
\text { sample based on tangent } \\
\text { neighborhoods (up to } \\
\text { 200m) }\end{array}$} & \multicolumn{2}{|c|}{$\begin{array}{l}\text { Natural experiment } \\
\text { sample based on } \\
\text { tangent neighborhoods } \\
\text { (up to } 250 \mathrm{~m} \text { ) }\end{array}$} & \multicolumn{3}{|c|}{$\begin{array}{c}\text { Tel Aviv District } 9 \\
\text { versus } \\
\text { Giv`ataim and Ramat Gan }\end{array}$} \\
\hline & $\begin{array}{c}1993 \\
(1) \\
\end{array}$ & $\begin{array}{c}1994 \\
(2) \\
\end{array}$ & $\begin{array}{c}1993 \\
(3) \\
\end{array}$ & $\begin{array}{c}1994 \\
(4) \\
\end{array}$ & $\begin{array}{c}1992 \\
(5) \\
\end{array}$ & $\begin{array}{c}1993 \\
(6) \\
\end{array}$ & $\begin{array}{c}1994 \\
(7) \\
\end{array}$ \\
\hline \multicolumn{8}{|l|}{ Father's years of schooling } \\
\hline Control group mean & 11.787 & 11.383 & 11.911 & 11.508 & 11.885 & 11.931 & 12.097 \\
\hline Treatment-control difference & $\begin{array}{l}-0.115 \\
(0.620)\end{array}$ & $\begin{array}{c}-0.377 \\
(0.954)\end{array}$ & $\begin{array}{c}-0.227 \\
(0.611)\end{array}$ & $\begin{array}{l}-0.397 \\
(0.898)\end{array}$ & $\begin{array}{l}-1.156 \\
(0.343)\end{array}$ & $\begin{array}{c}-1.179 \\
(0.339)\end{array}$ & $\begin{array}{l}-1.760 \\
(0.378)\end{array}$ \\
\hline \multicolumn{8}{|l|}{ Mother's years of schooling } \\
\hline Control group mean & 11.724 & 11.565 & 11.679 & 11.655 & 11.900 & 11.998 & 12.364 \\
\hline Treat-control difference & $\begin{array}{c}0.038 \\
(0.498)\end{array}$ & $\begin{array}{l}-0.295 \\
(0.943)\end{array}$ & $\begin{array}{c}0.033 \\
(0.573)\end{array}$ & $\begin{array}{c}-0.276 \\
(0.876)\end{array}$ & $\begin{array}{l}-1.064 \\
(0.312)\end{array}$ & $\begin{array}{l}-1.011 \\
(0.309)\end{array}$ & $\begin{array}{l}-1.798 \\
(0.382)\end{array}$ \\
\hline \multicolumn{8}{|l|}{ Number of siblings } \\
\hline Control group mean & 2.000 & 1.974 & 2.005 & 1.992 & 2.116 & 2.024 & 1.839 \\
\hline Treatment-control difference & $\begin{array}{c}0.266 \\
(0.175)\end{array}$ & $\begin{array}{c}0.112 \\
(0.312)\end{array}$ & $\begin{array}{c}0.171 \\
(0.149)\end{array}$ & $\begin{array}{c}0.171 \\
(0.272)\end{array}$ & $\begin{array}{c}0.148 \\
(0.093)\end{array}$ & $\begin{array}{c}0.234 \\
(0.077)\end{array}$ & $\begin{array}{c}0.306 \\
(0.110)\end{array}$ \\
\hline \multicolumn{8}{|l|}{ Gender (male=1) } \\
\hline Control group mean & 0.526 & 0.534 & 0.527 & 0.520 & 0.506 & 0.521 & 0.526 \\
\hline Treatment-control difference & $\begin{array}{c}0.047 \\
(0.054)\end{array}$ & $\begin{array}{c}-0.031 \\
(0.062)\end{array}$ & $\begin{array}{c}0.027 \\
(0.039)\end{array}$ & $\begin{array}{c}-0.025 \\
(0.061)\end{array}$ & $\begin{array}{c}0.006 \\
(0.027)\end{array}$ & $\begin{array}{c}0.004 \\
(0.019)\end{array}$ & $\begin{array}{l}-0.051 \\
(0.026)\end{array}$ \\
\hline \multicolumn{8}{|l|}{ Immigration status } \\
\hline Control group mean & 0.031 & 0.026 & 0.031 & 0.024 & 0.071 & 0.079 & 0.024 \\
\hline Treatment-control difference & $\begin{array}{c}0.081 \\
(0.044)\end{array}$ & $\begin{array}{c}0.048 \\
(0.052)\end{array}$ & $\begin{array}{c}0.076 \\
(0.038)\end{array}$ & $\begin{array}{c}0.039 \\
(0.043)\end{array}$ & $\begin{array}{c}0.010 \\
(0.019)\end{array}$ & $\begin{array}{c}0.010 \\
(0.018)\end{array}$ & $\begin{array}{c}0.028 \\
(0.016)\end{array}$ \\
\hline \multicolumn{8}{|l|}{ Country of origin - Israel } \\
\hline Control group mean & 0.604 & 0.653 & 0.621 & 0.655 & 0.591 & 0.609 & 0.603 \\
\hline Treatment-control difference & $\begin{array}{c}-0.003 \\
(0.055)\end{array}$ & $\begin{array}{c}-0.039 \\
(0.068)\end{array}$ & $\begin{array}{c}-0.039 \\
(0.053)\end{array}$ & $\begin{array}{c}-0.018 \\
(0.061)\end{array}$ & $\begin{array}{c}0.009 \\
(0.028)\end{array}$ & $\begin{array}{c}0.022 \\
(0.029)\end{array}$ & $\begin{array}{c}0.056 \\
(0.028)\end{array}$ \\
\hline \multicolumn{8}{|l|}{ Country of origin - Asia/Africa } \\
\hline Control group mean & 0.214 & 0.171 & 0.196 & 0.171 & 0.222 & 0.185 & 0.194 \\
\hline Treatment-control difference & $\begin{array}{c}-0.004 \\
(0.046)\end{array}$ & $\begin{array}{c}0.012 \\
(0.041)\end{array}$ & $\begin{array}{c}0.030 \\
(0.042)\end{array}$ & $\begin{array}{c}-0.018 \\
(0.039)\end{array}$ & $\begin{array}{c}0.033 \\
(0.024)\end{array}$ & $\begin{array}{c}0.038 \\
(0.020)\end{array}$ & $\begin{array}{c}0.002 \\
(0.023)\end{array}$ \\
\hline \multicolumn{8}{|l|}{ Country of origin - Europe/America } \\
\hline Control group mean & 0.125 & 0.114 & 0.116 & 0.115 & 0.086 & 0.098 & 0.102 \\
\hline Treatment-control difference & $\begin{array}{c}-0.069 \\
(0.031)\end{array}$ & $\begin{array}{c}-0.022 \\
(0.041)\end{array}$ & $\begin{array}{c}-0.054 \\
(0.029)\end{array}$ & $\begin{array}{c}-0.026 \\
(0.035)\end{array}$ & $\begin{array}{c}-0.038 \\
(0.015)\end{array}$ & $\begin{array}{c}-0.054 \\
(0.014)\end{array}$ & $\begin{array}{l}-0.055 \\
(0.014)\end{array}$ \\
\hline \multicolumn{8}{|l|}{ Number of students } \\
\hline Control group & 192 & 193 & 224 & 252 & 1876 & 1909 & 1842 \\
\hline Treatment group & 143 & 163 & 177 & 190 & 758 & 827 & 791 \\
\hline
\end{tabular}

Note: Standard errors in parentheses are adjusted for (primary) school level clustering. 
Table 3 - Simple, Controlled and Difference-in-Differences Effects of School Choice

\begin{tabular}{|c|c|c|c|c|c|c|c|c|c|c|c|}
\hline \multirow[b]{2}{*}{ Dependent variable } & \multicolumn{5}{|c|}{$\begin{array}{c}\text { Tel Aviv District } 9 \\
\text { versus } \\
\text { Giv`ataim and Ramat Gan }\end{array}$} & \multicolumn{3}{|c|}{$\begin{array}{l}\text { Natural experiment sample } \\
\text { based on tangent } \\
\text { neighborhoods (up to 200m) }\end{array}$} & \multicolumn{3}{|c|}{$\begin{array}{l}\text { Natural experiment sample } \\
\text { based on tangent } \\
\text { neighborhoods (up to } 250 \mathrm{~m} \text { ) }\end{array}$} \\
\hline & $\begin{array}{c}1992 \\
(1) \\
\end{array}$ & $\begin{array}{c}1993 \\
(2) \\
\end{array}$ & $\begin{array}{c}1994 \\
(3) \\
\end{array}$ & $\begin{array}{c}\text { DID } \\
92-' 94 \\
(4) \\
\end{array}$ & $\begin{array}{c}\text { DID } \\
93-' 94 \\
(5) \\
\end{array}$ & $\begin{array}{c}1993 \\
(6) \\
\end{array}$ & $\begin{array}{c}1994 \\
(7) \\
\end{array}$ & $\begin{array}{c}\text { DID } \\
93-' 94 \\
(8) \\
\end{array}$ & $\begin{array}{c}1993 \\
(9) \\
\end{array}$ & $\begin{array}{c}1994 \\
(10) \\
\end{array}$ & $\begin{array}{c}\text { DID } \\
93-' 94 \\
(11) \\
\end{array}$ \\
\hline \multicolumn{12}{|l|}{ Drop out } \\
\hline Control group mean & 0.087 & 0.086 & 0.099 & $\ldots$ & $\ldots$ & 0.083 & 0.088 & $\ldots$ & 0.080 & 0.087 & $\ldots$ \\
\hline Treatment-control difference & $\begin{array}{c}0.092 \\
(0.032)\end{array}$ & $\begin{array}{c}0.107 \\
(0.022)\end{array}$ & $\begin{array}{c}0.028 \\
(0.027)\end{array}$ & $\begin{array}{c}-0.068 \\
(0.016)\end{array}$ & $\begin{array}{c}-0.074 \\
(0.019)\end{array}$ & $\begin{array}{c}0.043 \\
(0.048)\end{array}$ & $\begin{array}{c}0.035 \\
(0.045)\end{array}$ & $\begin{array}{l}-0.034 \\
(0.045)\end{array}$ & $\begin{array}{c}0.061 \\
(0.046)\end{array}$ & $\begin{array}{c}0.023 \\
(0.043)\end{array}$ & $\begin{array}{l}-0.062 \\
(0.041)\end{array}$ \\
\hline Treatment-control controlled difference & $\begin{array}{c}0.047 \\
(0.027)\end{array}$ & $\begin{array}{c}0.054 \\
(0.020)\end{array}$ & $\begin{array}{l}-0.010 \\
(0.018)\end{array}$ & $\begin{array}{c}-0.080 \\
(0.015)\end{array}$ & $\begin{array}{c}-0.085 \\
(0.017)\end{array}$ & $\begin{array}{c}-0.010 \\
(0.045)\end{array}$ & $\begin{array}{c}0.017 \\
(0.034)\end{array}$ & $\begin{array}{l}-0.020 \\
(0.043)\end{array}$ & $\begin{array}{c}0.010 \\
(0.042)\end{array}$ & $\begin{array}{c}0.012 \\
(0.032)\end{array}$ & $\begin{array}{l}-0.040 \\
(0.038)\end{array}$ \\
\hline \multicolumn{12}{|l|}{ Eligibile for Bagrut } \\
\hline Control group mean & 0.603 & 0.634 & 0.621 & $\ldots$ & $\ldots$ & 0.583 & 0.539 & $\ldots$ & 0.594 & 0.536 & $\ldots$ \\
\hline Treatment-control difference & $\begin{array}{c}-0.165 \\
(0.0623)\end{array}$ & $\begin{array}{l}-0.188 \\
(0.043)\end{array}$ & $\begin{array}{c}-0.102 \\
(0.0471)\end{array}$ & $\begin{array}{c}0.073 \\
(0.025)\end{array}$ & $\begin{array}{c}0.080 \\
(0.029)\end{array}$ & $\begin{array}{c}-0.052 \\
(0.103)\end{array}$ & $\begin{array}{c}0.056 \\
(0.081)\end{array}$ & $\begin{array}{c}0.127 \\
(0.073)\end{array}$ & $\begin{array}{c}-0.097 \\
(0.095)\end{array}$ & $\begin{array}{c}0.059 \\
(0.078)\end{array}$ & $\begin{array}{c}0.163 \\
(0.066)\end{array}$ \\
\hline Treatment-control controlled difference & $\begin{array}{c}0.013 \\
(0.0503)\end{array}$ & $\begin{array}{c}-0.048 \\
(0.025)\end{array}$ & $\begin{array}{c}-0.006 \\
(0.031)\end{array}$ & $\begin{array}{c}0.054 \\
(0.024)\end{array}$ & $\begin{array}{c}0.068 \\
(0.027)\end{array}$ & $\begin{array}{c}0.030 \\
(0.069)\end{array}$ & $\begin{array}{c}0.176 \\
(0.064)\end{array}$ & $\begin{array}{c}0.129 \\
(0.073)\end{array}$ & $\begin{array}{c}0.024 \\
(0.065)\end{array}$ & $\begin{array}{c}0.137 \\
(0.053)\end{array}$ & $\begin{array}{c}0.122 \\
(0.065)\end{array}$ \\
\hline \multicolumn{12}{|l|}{ Average score } \\
\hline Control group mean & 75.641 & 76.826 & 75.934 & $\ldots$ & $\ldots$ & 76.537 & 74.156 & $\ldots$ & 76.894 & 75.318 & $\ldots$ \\
\hline Treatment-control difference & $\begin{array}{l}-15.645 \\
(3.9644)\end{array}$ & $\begin{array}{c}-16.771 \\
(2.917)\end{array}$ & $\begin{array}{c}-9.235 \\
3.764\end{array}$ & $\begin{array}{c}6.729 \\
(1.594)\end{array}$ & $\begin{array}{c}6.941 \\
(1.807)\end{array}$ & $\begin{array}{c}-10.989 \\
(6.409)\end{array}$ & $\begin{array}{l}-2.847 \\
(5.842)\end{array}$ & $\begin{array}{l}10.414 \\
(4.488)\end{array}$ & $\begin{array}{c}-13.120 \\
(6.341)\end{array}$ & $\begin{array}{l}-2.703 \\
(5.246)\end{array}$ & $\begin{array}{l}11.692 \\
(4.038)\end{array}$ \\
\hline Treatment-control controlled difference & $\begin{array}{c}-5.200 \\
(2.7061)\end{array}$ & $\begin{array}{l}-7.830 \\
(1.951)\end{array}$ & $\begin{array}{c}-1.595 \\
2.285\end{array}$ & $\begin{array}{c}6.824 \\
(1.453)\end{array}$ & $\begin{array}{c}7.337 \\
(1.658)\end{array}$ & $\begin{array}{l}-3.735 \\
(3.584)\end{array}$ & $\begin{array}{c}2.108 \\
(4.102)\end{array}$ & $\begin{array}{c}9.461 \\
(4.269)\end{array}$ & $\begin{array}{l}-5.081 \\
(3.594)\end{array}$ & $\begin{array}{c}1.696 \\
(2.990)\end{array}$ & $\begin{array}{c}8.858 \\
(3.787)\end{array}$ \\
\hline \multicolumn{12}{|l|}{ Number of students } \\
\hline Control group & 1,876 & 1,909 & 1,842 & 7,105 & 4,532 & 192 & 193 & 524 & 224 & 252 & 649 \\
\hline Treatment group & 758 & 827 & 791 & 791 & 791 & 143 & 163 & 163 & 177 & 190 & 190 \\
\hline
\end{tabular}

Note: Standard errors in parentheses are adjusted for (primary) school level clustering. DID = Difference-in-Differences. 
Table 3 (continued) - Simple, Controlled and Difference-in-Differences Effects of School Choice

\begin{tabular}{|c|c|c|c|c|c|c|c|c|c|c|c|}
\hline \multirow[b]{2}{*}{ Dependent variable } & \multicolumn{5}{|c|}{$\begin{array}{c}\text { Tel Aviv District } 9 \\
\text { versus } \\
\text { Giv`ataim and Ramat Gan }\end{array}$} & \multicolumn{3}{|c|}{$\begin{array}{l}\text { Natural experiment sample } \\
\text { based on tangent } \\
\text { neighborhoods (up to 200m) }\end{array}$} & \multicolumn{3}{|c|}{$\begin{array}{l}\text { Natural experiment sample } \\
\text { based on tangent } \\
\text { neighborhoods (up to } 250 \mathrm{~m} \text { ) }\end{array}$} \\
\hline & $\begin{array}{c}1992 \\
(1) \\
\end{array}$ & $\begin{array}{c}1993 \\
(2) \\
\end{array}$ & $\begin{array}{c}1994 \\
(3) \\
\end{array}$ & $\begin{array}{c}\text { DID } \\
92-' 94 \\
(4) \\
\end{array}$ & $\begin{array}{c}\text { DID } \\
93-' 94 \\
(5) \\
\end{array}$ & $\begin{array}{c}1993 \\
(6) \\
\end{array}$ & $\begin{array}{c}1994 \\
(7) \\
\end{array}$ & $\begin{array}{c}\text { DID } \\
93-' 94 \\
(8) \\
\end{array}$ & $\begin{array}{c}1993 \\
(9) \\
\end{array}$ & $\begin{array}{c}1994 \\
(10) \\
\end{array}$ & $\begin{array}{c}\text { DID } \\
93-' 94 \\
(11) \\
\end{array}$ \\
\hline \multicolumn{12}{|l|}{ Number of Bagrut credits } \\
\hline Control group mean & 19.979 & 20.753 & 20.305 & $\ldots$ & $\ldots$ & 20.662 & 19.446 & $\ldots$ & 20.817 & 19.746 & $\ldots$ \\
\hline Treatment-control difference & $\begin{array}{c}-4.270 \\
(1.1431)\end{array}$ & $\begin{array}{l}-4.958 \\
(0.964)\end{array}$ & $\begin{array}{c}-2.731 \\
(1.100)\end{array}$ & $\begin{array}{c}1.866 \\
(0.517)\end{array}$ & $\begin{array}{c}2.090 \\
(0.593)\end{array}$ & $\begin{array}{l}-2.550 \\
(1.926)\end{array}$ & $\begin{array}{l}-0.433 \\
(1.482)\end{array}$ & $\begin{array}{c}2.859 \\
(1.491)\end{array}$ & $\begin{array}{c}-3.393 \\
(1.744)\end{array}$ & $\begin{array}{l}-0.488 \\
(1.414)\end{array}$ & $\begin{array}{c}3.219 \\
(1.348)\end{array}$ \\
\hline Treatment-control controlled difference & $\begin{array}{c}-0.995 \\
(0.7934)\end{array}$ & $\begin{array}{c}-1.561 \\
(0.608)\end{array}$ & $\begin{array}{c}-0.490 \\
(0.780)\end{array}$ & $\begin{array}{c}1.694 \\
(0.486)\end{array}$ & $\begin{array}{c}1.846 \\
(0.559)\end{array}$ & $\begin{array}{c}-0.455 \\
(1.378)\end{array}$ & $\begin{array}{c}1.038 \\
(1.016)\end{array}$ & $\begin{array}{c}2.880 \\
(1.440)\end{array}$ & $\begin{array}{c}-0.764 \\
(1.140)\end{array}$ & $\begin{array}{c}0.517 \\
(1.037)\end{array}$ & $\begin{array}{c}2.268 \\
(1.289)\end{array}$ \\
\hline \multicolumn{12}{|l|}{ Number of science credits } \\
\hline Control group mean & 3.056 & 3.012 & 2.887 & $\ldots$ & $\ldots$ & 3.214 & 2.606 & $\ldots$ & 3.219 & 2.810 & $\ldots$ \\
\hline Treatment-control difference & $\begin{array}{c}-1.468 \\
(0.4005)\end{array}$ & $\begin{array}{l}-1.516 \\
(0.263)\end{array}$ & $\begin{array}{l}-1.157 \\
(0.299)\end{array}$ & $\begin{array}{c}0.317 \\
(0.199)\end{array}$ & $\begin{array}{c}0.319 \\
(0.226)\end{array}$ & $\begin{array}{l}-1.249 \\
(0.607)\end{array}$ & $\begin{array}{c}-0.232 \\
(0.571)\end{array}$ & $\begin{array}{c}1.045 \\
(0.583)\end{array}$ & $\begin{array}{c}-1.366 \\
(0.563)\end{array}$ & $\begin{array}{l}-0.346 \\
(0.599)\end{array}$ & $\begin{array}{c}1.022 \\
(0.529)\end{array}$ \\
\hline Treatment-control controlled difference & $\begin{array}{c}-0.255 \\
(0.2571)\end{array}$ & $\begin{array}{c}-0.581 \\
(0.184)\end{array}$ & $\begin{array}{c}-0.264 \\
(0.173)\end{array}$ & $\begin{array}{c}0.285 \\
(0.192)\end{array}$ & $\begin{array}{c}0.325 \\
(0.217)\end{array}$ & $\begin{array}{c}-0.485 \\
(0.247)\end{array}$ & $\begin{array}{c}0.338 \\
(0.343)\end{array}$ & $\begin{array}{c}0.844 \\
(0.558)\end{array}$ & $\begin{array}{c}-0.268 \\
(0.296)\end{array}$ & $\begin{array}{c}0.098 \\
(0.306)\end{array}$ & $\begin{array}{c}0.391 \\
(0.502)\end{array}$ \\
\hline \multicolumn{12}{|l|}{ Number of honor-level subjects } \\
\hline Control group mean & 2.259 & 2.376 & 2.342 & $\ldots$ & $\ldots$ & 2.458 & 2.207 & $\ldots$ & 2.464 & 2.250 & $\ldots$ \\
\hline Treatment-control difference & $\begin{array}{c}-0.757 \\
(0.1671)\end{array}$ & $\begin{array}{l}-0.825 \\
(0.144)\end{array}$ & $\begin{array}{c}-0.567 \\
(0.157)\end{array}$ & $\begin{array}{c}0.224 \\
(0.077)\end{array}$ & $\begin{array}{c}0.246 \\
(0.089)\end{array}$ & $\begin{array}{c}-0.577 \\
(0.298)\end{array}$ & $\begin{array}{c}-0.140 \\
(0.271)\end{array}$ & $\begin{array}{c}0.513 \\
(0.224)\end{array}$ & $\begin{array}{c}-0.685 \\
(0.273)\end{array}$ & $\begin{array}{l}-0.150 \\
(0.253)\end{array}$ & $\begin{array}{c}0.557 \\
(0.203)\end{array}$ \\
\hline Treatment-control controlled difference & $\begin{array}{c}-0.240 \\
(0.1046)\end{array}$ & $\begin{array}{c}-0.291 \\
(0.093)\end{array}$ & $\begin{array}{c}-0.176 \\
(0.098)\end{array}$ & $\begin{array}{c}0.183 \\
(0.072)\end{array}$ & $\begin{array}{c}0.195 \\
(0.084)\end{array}$ & $\begin{array}{c}-0.257 \\
(0.195)\end{array}$ & $\begin{array}{c}0.175 \\
(0.171)\end{array}$ & $\begin{array}{c}0.550 \\
(0.215)\end{array}$ & $\begin{array}{c}-0.261 \\
(0.164)\end{array}$ & $\begin{array}{c}0.097 \\
(0.140)\end{array}$ & $\begin{array}{c}0.408 \\
(0.193)\end{array}$ \\
\hline \multicolumn{12}{|l|}{ Number of students } \\
\hline Control group & 1,876 & 1,909 & 1,842 & 7,105 & 4,532 & 192 & 193 & 524 & 224 & 252 & 649 \\
\hline Treatment group & 758 & 827 & 791 & 791 & 791 & 143 & 163 & 163 & 177 & 190 & 190 \\
\hline
\end{tabular}

Note: Standard errors in parentheses are adjusted for (primary) school level clustering. DID = Difference-in-Differences. 
Table 4 - Difference-in-Differences Effects of School Choice by Student Background (Tel Aviv District 9 versus Giv`ataim \& Ramat Gan, 1994 versus 1992-1993)

\begin{tabular}{|c|c|c|c|c|}
\hline Dependent variable & $\begin{array}{c}\text { Low father } \\
\text { schooling } \\
(1)\end{array}$ & $\begin{array}{c}\text { High father } \\
\text { schooling } \\
(2) \\
\end{array}$ & $\begin{array}{l}\text { Boys } \\
(3) \\
\end{array}$ & $\begin{array}{l}\text { Girls } \\
(4) \\
\end{array}$ \\
\hline Drop out & $\begin{array}{c}-0.069 \\
(0.026)\end{array}$ & $\begin{array}{l}-0.048 \\
(0.019)\end{array}$ & $\begin{array}{c}-0.116 \\
(0.024)\end{array}$ & $\begin{array}{c}-0.033 \\
(0.017)\end{array}$ \\
\hline Eligibilie for Bagrut & $\begin{array}{c}0.062 \\
(0.036)\end{array}$ & $\begin{array}{c}-0.005 \\
(0.034)\end{array}$ & $\begin{array}{c}0.045 \\
(0.034)\end{array}$ & $\begin{array}{c}0.065 \\
(0.033)\end{array}$ \\
\hline Average score & $\begin{array}{c}5.976 \\
(2.359)\end{array}$ & $\begin{array}{c}3.867 \\
(1.976)\end{array}$ & $\begin{array}{c}9.200 \\
(2.212)\end{array}$ & $\begin{array}{c}3.704 \\
(1.864)\end{array}$ \\
\hline Number of Bagrut credits & $\begin{array}{c}1.458 \\
(0.770)\end{array}$ & $\begin{array}{c}0.550 \\
(0.676)\end{array}$ & $\begin{array}{c}2.564 \\
(0.759)\end{array}$ & $\begin{array}{c}0.635 \\
(0.598)\end{array}$ \\
\hline Number of science credits & $\begin{array}{c}0.267 \\
(0.234)\end{array}$ & $\begin{array}{c}0.032 \\
(0.312)\end{array}$ & $\begin{array}{c}0.118 \\
(0.275)\end{array}$ & $\begin{array}{c}0.324 \\
(0.266)\end{array}$ \\
\hline Number of honor-level subjects & $\begin{array}{c}0.141 \\
(0.105)\end{array}$ & $\begin{array}{c}0.093 \\
(0.108)\end{array}$ & $\begin{array}{c}0.263 \\
(0.112)\end{array}$ & $\begin{array}{c}0.081 \\
(0.091)\end{array}$ \\
\hline $\begin{array}{l}\text { Number of students } \\
\text { Control group } \\
\text { Treatment group }\end{array}$ & $\begin{array}{c}2,801 \\
462\end{array}$ & $\begin{array}{c}4,304 \\
329\end{array}$ & $\begin{array}{c}3,676 \\
376\end{array}$ & $\begin{array}{c}3,429 \\
415\end{array}$ \\
\hline
\end{tabular}

Note: Standard errors in parentheses are adjusted for (primary) school level clustering. Low schooling is defined as less than 12 years of education. All regressions control for school and year effects, and student covariates. 
Table 5 - OLS Regressions of Opting Out on High School Outcomes

Tel Aviv District 9, 1994

\begin{tabular}{|c|c|c|c|c|c|c|c|}
\hline Definitions of Opting Out & Controls & $\begin{array}{c}\text { Drop out } \\
(1) \\
\end{array}$ & $\begin{array}{c}\text { Bagrut } \\
\text { Eligibility } \\
(2) \\
\end{array}$ & $\begin{array}{c}\text { Average score } \\
\text { (3) } \\
\end{array}$ & $\begin{array}{c}\text { Bagrut credits } \\
\text { (4) } \\
\end{array}$ & $\begin{array}{c}\text { Science credits } \\
\text { (5) } \\
\end{array}$ & $\begin{array}{c}\text { Honor level } \\
\text { subjects } \\
(6) \\
\end{array}$ \\
\hline Mean of stayers in district 9 & & 0.142 & 0.479 & 63.418 & 17.242 & 1.337 & 1.638 \\
\hline Opting out to districts 1-4 & No & $\begin{array}{l}-0.049 \\
(0.023)\end{array}$ & $\begin{array}{c}0.127 \\
(0.059)\end{array}$ & $\begin{array}{c}9.200 \\
(3.550)\end{array}$ & $\begin{array}{c}1.079 \\
(1.094)\end{array}$ & $\begin{array}{c}0.799 \\
(0.392)\end{array}$ & $\begin{array}{c}0.285 \\
(0.160)\end{array}$ \\
\hline Opting out to districts 1-4 & Yes & $\begin{array}{c}-0.042 \\
(0.014)\end{array}$ & $\begin{array}{c}0.050 \\
(0.049)\end{array}$ & $\begin{array}{c}4.548 \\
(2.700)\end{array}$ & $\begin{array}{l}-0.366 \\
(0.816)\end{array}$ & $\begin{array}{c}0.270 \\
(0.214)\end{array}$ & $\begin{array}{c}0.033 \\
(0.113)\end{array}$ \\
\hline Opting out to districts 1-8 & No & $\begin{array}{c}-0.029 \\
(0.025)\end{array}$ & $\begin{array}{c}0.083 \\
(0.063)\end{array}$ & $\begin{array}{c}6.654 \\
(3.727)\end{array}$ & $\begin{array}{c}0.674 \\
(1.131)\end{array}$ & $\begin{array}{c}0.797 \\
(0.369)\end{array}$ & $\begin{array}{c}0.277 \\
(0.162)\end{array}$ \\
\hline Opting out to districts 1-8 & Yes & $\begin{array}{c}-0.032 \\
(0.018)\end{array}$ & $\begin{array}{c}0.018 \\
(0.052)\end{array}$ & $\begin{array}{c}3.381 \\
(2.897)\end{array}$ & $\begin{array}{c}-0.644 \\
(0.858)\end{array}$ & $\begin{array}{c}0.313 \\
(0.222)\end{array}$ & $\begin{array}{c}0.025 \\
(0.121)\end{array}$ \\
\hline
\end{tabular}

Note: Standard errors in parentheses are adjusted for (primary) school level clustering.

The endogenous variables are defined as enrolling in a school in district 9. 
Table 6 - Descriptive Statistics and Balancing Tests for Instruments for Opting Out

Tel Aviv District 9, 1993-1994

\begin{tabular}{|c|c|c|c|c|c|c|c|c|}
\hline & \multicolumn{2}{|c|}{ Instrument 1 (1994) } & \multicolumn{2}{|c|}{ Instrument 2 (1993) } & \multicolumn{2}{|c|}{ Instrument 2 (1994) } & \multicolumn{2}{|c|}{ Instrument 3 (1994) } \\
\hline Dependent variable & $\begin{array}{c}\text { Mean in } \\
\text { district } 9 \\
(1)\end{array}$ & $\begin{array}{c}\text { Estimated } \\
\text { coefficient } \\
(2) \\
\end{array}$ & $\begin{array}{c}\text { Mean if } \\
\text { instrument }=0 \\
(3)\end{array}$ & $\begin{array}{c}\text { Estimated } \\
\text { difference } \\
(4) \\
\end{array}$ & $\begin{array}{c}\text { Mean if } \\
\text { instrument }=0 \\
(5)\end{array}$ & $\begin{array}{c}\text { Estimated } \\
\text { difference } \\
(6)\end{array}$ & $\begin{array}{c}\text { Mean if } \\
\text { instrument }=0 \\
(7)\end{array}$ & $\begin{array}{c}\text { Estimated } \\
\text { difference } \\
(8)\end{array}$ \\
\hline Father's years of schooling & 10.861 & $\begin{array}{c}0.365 \\
(0.444)\end{array}$ & 10.614 & $\begin{array}{c}-0.218 \\
(0.450)\end{array}$ & 10.888 & $\begin{array}{l}-0.180 \\
(0.364)\end{array}$ & 10.912 & $\begin{array}{c}-0.217 \\
(0.522)\end{array}$ \\
\hline Mother's years of schooling & 11.105 & $\begin{array}{c}0.588 \\
(0.400)\end{array}$ & 10.867 & $\begin{array}{c}-0.089 \\
(0.476)\end{array}$ & 11.186 & $\begin{array}{c}-0.546 \\
(0.307)\end{array}$ & 11.118 & $\begin{array}{c}0.217 \\
(0.483)\end{array}$ \\
\hline Number of siblings & 2.421 & $\begin{array}{c}0.166 \\
(0.045)\end{array}$ & 2.205 & $\begin{array}{c}-0.117 \\
(0.177)\end{array}$ & 2.437 & $\begin{array}{c}-0.110 \\
(0.112)\end{array}$ & 2.385 & $\begin{array}{c}-0.129 \\
(0.335)\end{array}$ \\
\hline Gender (male=1) & 0.475 & $\begin{array}{c}0.046 \\
(0.015)\end{array}$ & 0.527 & $\begin{array}{c}-0.010 \\
(0.071)\end{array}$ & 0.475 & $\begin{array}{c}0.004 \\
(0.029)\end{array}$ & 0.479 & $\begin{array}{c}-0.081 \\
(0.058)\end{array}$ \\
\hline Immigration status & 0.052 & $\begin{array}{c}-0.030 \\
(0.013)\end{array}$ & 0.084 & $\begin{array}{c}0.023 \\
(0.036)\end{array}$ & 0.055 & $\begin{array}{c}-0.021 \\
(0.022)\end{array}$ & 0.057 & $\begin{array}{c}0.012 \\
(0.020)\end{array}$ \\
\hline Country of origin - Israel & 0.659 & $\begin{array}{c}0.047 \\
(0.020)\end{array}$ & 0.643 & $\begin{array}{c}0.066 \\
(0.040)\end{array}$ & 0.659 & $\begin{array}{c}-0.004 \\
(0.068)\end{array}$ & 0.663 & $\begin{array}{c}-0.115 \\
(0.058)\end{array}$ \\
\hline Country of origin - Asia/Africa & 0.196 & $\begin{array}{c}-0.039 \\
(0.018)\end{array}$ & 0.220 & $\begin{array}{c}0.015 \\
(0.038)\end{array}$ & 0.192 & $\begin{array}{c}0.027 \\
(0.065)\end{array}$ & 0.187 & $\begin{array}{c}0.092 \\
(0.066)\end{array}$ \\
\hline Country of origin - Europe/America & 0.047 & $\begin{array}{c}0.027 \\
(0.018)\end{array}$ & 0.044 & $\begin{array}{c}-0.004 \\
(0.020)\end{array}$ & 0.045 & $\begin{array}{c}0.014 \\
(0.020)\end{array}$ & 0.041 & $\begin{array}{c}0.044 \\
(0.041)\end{array}$ \\
\hline Number of students & 672 & 119 & 678 & 149 & 672 & 119 & 700 & 772 \\
\hline
\end{tabular}

Note: Standard errors in parentheses are adjusted for (primary) school clustering.

Definitions of Instruments:

Instrument 1 is the distance to the high schools campus in district 9.

Instrument $2=1$ if student residing on a bus route, 0 otherwise.

Instrument 3 = 1 for all students with older siblings eligible for bussing, 0 otherwise. 
Table 7 - IV Estimates of Effect of Opting Out of Own District Schools Using Each Instrument Separately

\begin{tabular}{|c|c|c|c|c|c|c|c|c|}
\hline & & $\begin{array}{l}\text { First stage: } \\
\text { Opting out }\end{array}$ & Drop out & $\begin{array}{c}\text { Bagrut } \\
\text { Eligibility }\end{array}$ & $\begin{array}{c}\text { Average } \\
\text { score }\end{array}$ & $\begin{array}{l}\text { Bagrut } \\
\text { credits }\end{array}$ & $\begin{array}{c}\text { Science } \\
\text { credits }\end{array}$ & $\begin{array}{c}\text { Honor level } \\
\text { subjects }\end{array}$ \\
\hline Instruments used & Covariates included & $(1)$ & $(2)$ & (3) & (4) & (5) & (6) & (7) \\
\hline & & & \multicolumn{6}{|c|}{ A. Reduced form } \\
\hline Instrument 1 & No & $\begin{array}{c}0.225 \\
(0.026)\end{array}$ & $\begin{array}{c}0.001 \\
(0.028)\end{array}$ & $\begin{array}{c}0.021 \\
(0.067)\end{array}$ & $\begin{array}{c}1.896 \\
(4.817)\end{array}$ & $\begin{array}{c}-0.171 \\
(1.463)\end{array}$ & $\begin{array}{c}0.402 \\
(0.411)\end{array}$ & $\begin{array}{c}0.073 \\
(0.219)\end{array}$ \\
\hline Instrument 1 & Yes & $\begin{array}{c}0.248 \\
(0.029)\end{array}$ & $\begin{array}{c}0.011 \\
(0.011)\end{array}$ & $\begin{array}{l}-0.002 \\
(0.016)\end{array}$ & $\begin{array}{c}0.436 \\
(1.377)\end{array}$ & $\begin{array}{l}-0.512 \\
(0.566)\end{array}$ & $\begin{array}{c}0.255 \\
(0.080)\end{array}$ & $\begin{array}{c}-0.024 \\
(0.073)\end{array}$ \\
\hline Instrument 2 & No & $\begin{array}{l}-0.234 \\
(0.051)\end{array}$ & $\begin{array}{c}0.051 \\
(0.037)\end{array}$ & $\begin{array}{l}-0.051 \\
(0.056)\end{array}$ & $\begin{array}{l}-1.892 \\
(4.402)\end{array}$ & $\begin{array}{l}-1.648 \\
(1.293)\end{array}$ & $\begin{array}{l}-0.012 \\
(0.588)\end{array}$ & $\begin{array}{l}-0.087 \\
(0.197)\end{array}$ \\
\hline Instrument 2 & Yes & $\begin{array}{l}-0.191 \\
(0.053)\end{array}$ & $\begin{array}{c}0.044 \\
(0.037)\end{array}$ & $\begin{array}{l}-0.047 \\
(0.035)\end{array}$ & $\begin{array}{l}-0.896 \\
(3.644)\end{array}$ & $\begin{array}{l}-1.737 \\
(1.124)\end{array}$ & $\begin{array}{l}-0.029 \\
(0.490)\end{array}$ & $\begin{array}{l}-0.154 \\
(0.159)\end{array}$ \\
\hline Instrument 3 & No & $\begin{array}{c}0.606 \\
(0.078)\end{array}$ & $\begin{array}{c}0.036 \\
(0.063)\end{array}$ & $\begin{array}{l}-0.011 \\
(0.060)\end{array}$ & $\begin{array}{c}3.170 \\
(5.785)\end{array}$ & $\begin{array}{c}1.926 \\
(1.771)\end{array}$ & $\begin{array}{c}0.577 \\
(0.297)\end{array}$ & $\begin{array}{c}0.336 \\
(0.171)\end{array}$ \\
\hline \multirow[t]{2}{*}{ Instrument 3} & Yes & $\begin{array}{c}0.576 \\
(0.080)\end{array}$ & $\begin{array}{c}0.046 \\
(0.054)\end{array}$ & $\begin{array}{c}0.016 \\
(0.066)\end{array}$ & $\begin{array}{c}3.544 \\
(5.289)\end{array}$ & $\begin{array}{c}2.543 \\
(1.531)\end{array}$ & $\begin{array}{c}0.922 \\
(0.423)\end{array}$ & $\begin{array}{c}0.483 \\
(0.162)\end{array}$ \\
\hline & & & \multicolumn{6}{|c|}{ B. 2SLS } \\
\hline Instrument 1 & Yes & $\begin{array}{l}\cdots \\
\cdots\end{array}$ & $\begin{array}{c}0.046 \\
(0.047)\end{array}$ & $\begin{array}{c}-0.009 \\
(0.071)\end{array}$ & $\begin{array}{c}1.760 \\
(6.114)\end{array}$ & $\begin{array}{l}-2.066 \\
(2.370)\end{array}$ & $\begin{array}{c}1.031 \\
(0.333)\end{array}$ & $\begin{array}{l}-0.096 \\
(0.316)\end{array}$ \\
\hline Instrument 2 & Yes & $\begin{array}{l}\cdots \\
\cdots\end{array}$ & $\begin{array}{c}0.231 \\
(0.186)\end{array}$ & $\begin{array}{l}-0.245 \\
(0.200)\end{array}$ & $\begin{array}{c}-4.684 \\
(20.408)\end{array}$ & $\begin{array}{l}-9.083 \\
(6.263)\end{array}$ & $\begin{array}{l}-0.152 \\
(2.795)\end{array}$ & $\begin{array}{l}-0.807 \\
(0.911)\end{array}$ \\
\hline Instrument 3 & Yes & $\begin{array}{l}\ldots \\
\ldots\end{array}$ & $\begin{array}{l}-0.080 \\
(0.107)\end{array}$ & $\begin{array}{c}-0.028 \\
(0.125)\end{array}$ & $\begin{array}{l}-6.157 \\
(9.601)\end{array}$ & $\begin{array}{l}-4.417 \\
(2.661)\end{array}$ & $\begin{array}{l}-1.601 \\
(0.916)\end{array}$ & $\begin{array}{l}-0.839 \\
(0.320)\end{array}$ \\
\hline
\end{tabular}

Note: Standard errors in parentheses are adjusted for (primary) school clustering. The controls are student's background characteristics.

Definitions of Instruments: Instrument 1 is the distance to the high schools campus in district 9 . Instrument $2=1$ if student residing on a bus route, 0 otherwise. Instrument $3=1$

for all students with older siblings eligible for bussing, 0 otherwise. 
Table 8 - IV Estimates of Effect of Opting Out of Own District Schools Using the Three Instruments Jointly

\begin{tabular}{|c|c|c|c|c|c|c|c|c|}
\hline $\begin{array}{l}\text { Instruments } \\
\text { used }\end{array}$ & $\begin{array}{c}\text { Covariates } \\
\text { included }\end{array}$ & $\begin{array}{c}\text { First stage: } \\
\text { Opting out } \\
\text { (1) }\end{array}$ & $\begin{array}{c}\text { Drop out } \\
\text { (2) }\end{array}$ & $\begin{array}{l}\text { Bagrut } \\
\text { Eligibility } \\
\text { (3) }\end{array}$ & $\begin{array}{c}\text { Average } \\
\text { score } \\
\text { (4) }\end{array}$ & $\begin{array}{l}\text { Bagrut } \\
\text { credits } \\
\text { (5) }\end{array}$ & $\begin{array}{l}\text { Science } \\
\text { credits } \\
\text { (6) }\end{array}$ & $\begin{array}{c}\text { Honor level } \\
\text { subjects } \\
\text { (7) }\end{array}$ \\
\hline & & & \multicolumn{6}{|c|}{ A. Reduced form } \\
\hline Instrument 1 & No & $\begin{array}{c}0.111 \\
(0.035)\end{array}$ & $\begin{array}{l}-0.024 \\
(0.033)\end{array}$ & $\begin{array}{c}0.044 \\
(0.078)\end{array}$ & $\begin{array}{c}4.041 \\
(5.822)\end{array}$ & $\begin{array}{c}1.033 \\
(1.619)\end{array}$ & $\begin{array}{c}0.390 \\
(0.491)\end{array}$ & $\begin{array}{c}0.173 \\
(0.240)\end{array}$ \\
\hline Instrument 1 & Yes & $\begin{array}{c}0.135 \\
(0.024)\end{array}$ & $\begin{array}{l}-0.013 \\
(0.015)\end{array}$ & $\begin{array}{c}0.027 \\
(0.025)\end{array}$ & $\begin{array}{c}2.396 \\
(1.413)\end{array}$ & $\begin{array}{c}0.897 \\
(0.507)\end{array}$ & $\begin{array}{c}0.179 \\
(0.138)\end{array}$ & $\begin{array}{c}0.118 \\
(0.065)\end{array}$ \\
\hline Instrument 2 & No & $\begin{array}{l}-0.151 \\
(0.041)\end{array}$ & $\begin{array}{l}-0.045 \\
(0.039)\end{array}$ & $\begin{array}{c}0.036 \\
(0.048)\end{array}$ & $\begin{array}{c}0.967 \\
(4.454)\end{array}$ & $\begin{array}{c}0.923 \\
(1.212)\end{array}$ & $\begin{array}{c}0.043 \\
(0.522)\end{array}$ & $\begin{array}{c}0.032 \\
(0.177)\end{array}$ \\
\hline Instrument 2 & Yes & $\begin{array}{l}-0.118 \\
(0.033)\end{array}$ & $\begin{array}{l}-0.032 \\
(0.034)\end{array}$ & $\begin{array}{c}0.028 \\
(0.033)\end{array}$ & $\begin{array}{l}-0.709 \\
(3.477)\end{array}$ & $\begin{array}{c}0.991 \\
(0.955)\end{array}$ & $\begin{array}{c}0.079 \\
(0.464)\end{array}$ & $\begin{array}{c}0.100 \\
(0.154)\end{array}$ \\
\hline Instrument 3 & No & $\begin{array}{c}0.547 \\
(0.079)\end{array}$ & $\begin{array}{l}-0.042 \\
(0.062)\end{array}$ & $\begin{array}{l}-0.001 \\
(0.057)\end{array}$ & $\begin{array}{l}-3.969 \\
(5.823)\end{array}$ & $\begin{array}{l}-1.867 \\
(1.642)\end{array}$ & $\begin{array}{l}-0.758 \\
(0.323)\end{array}$ & $\begin{array}{l}-0.342 \\
(0.159)\end{array}$ \\
\hline \multirow[t]{2}{*}{ Instrument 3} & Yes & $\begin{array}{c}0.533 \\
(0.080)\end{array}$ & $\begin{array}{l}-0.059 \\
(0.053)\end{array}$ & $\begin{array}{l}-0.017 \\
(0.069)\end{array}$ & $\begin{array}{l}-2.650 \\
(5.600)\end{array}$ & $\begin{array}{l}-2.141 \\
(1.591)\end{array}$ & $\begin{array}{l}-1.031 \\
(0.461)\end{array}$ & $\begin{array}{l}-0.436 \\
(0.178)\end{array}$ \\
\hline & & & \multicolumn{6}{|c|}{ B. 2SLS } \\
\hline Instrument $1+2+3$ & No & $\begin{array}{l}\ldots \\
\ldots\end{array}$ & $\begin{array}{l}-0.051 \\
(0.116)\end{array}$ & $\begin{array}{c}0.051 \\
(0.216)\end{array}$ & $\begin{array}{c}2.416 \\
(17.050)\end{array}$ & $\begin{array}{l}-1.038 \\
(5.091)\end{array}$ & $\begin{array}{l}-0.150 \\
(1.437)\end{array}$ & $\begin{array}{l}-0.085 \\
(0.671)\end{array}$ \\
\hline Instrument $1+2+3$ & Yes & $\begin{array}{l}\ldots \\
\ldots\end{array}$ & $\begin{array}{l}-0.068 \\
(0.098)\end{array}$ & $\begin{array}{c}0.008 \\
(0.129)\end{array}$ & $\begin{array}{c}2.168 \\
(9.265)\end{array}$ & $\begin{array}{l}-1.647 \\
(2.989)\end{array}$ & $\begin{array}{l}-0.940 \\
(0.873)\end{array}$ & $\begin{array}{l}-0.374 \\
(0.338)\end{array}$ \\
\hline
\end{tabular}

Note: Standard errors in parentheses are adjusted for (primary) school clustering. The controls are student's background characteristics.

Definitions of Instruments: Instrument 1 is the distance to the high schools campus in district 9 . Instrument $2=1$ if student residing on a bus route, 0 otherwise. Instrument 3

$=1$ for all students with older siblings eligible for bussing, 0 otherwise. 
TABLE A1 - DIFFERENCES IN DIFFERENCES ESTIMATES

District 9 versus Givataim and Ramat Gan and versus Bat Yam and Holon 1994 against 1992-1993

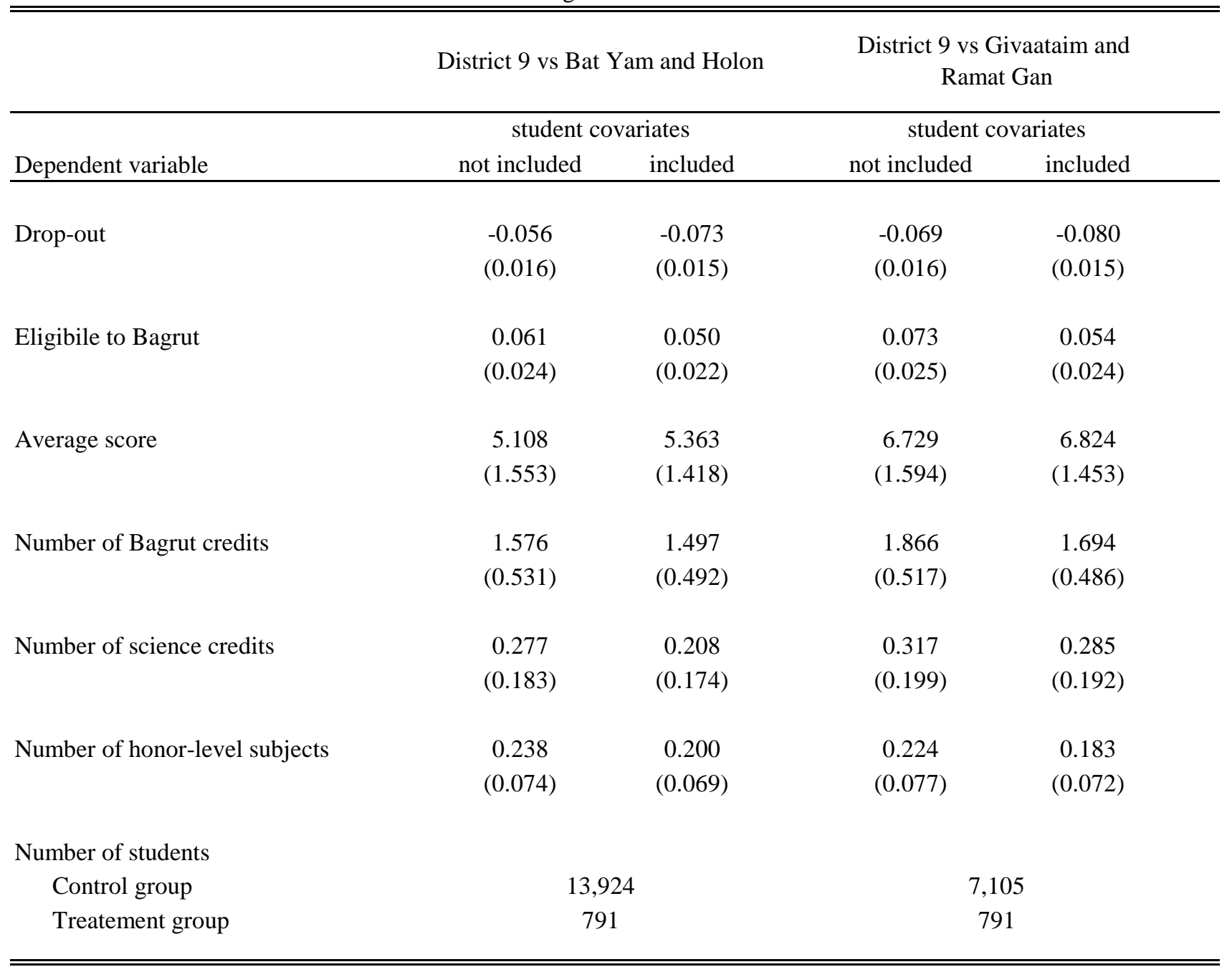

Note: Standard errors in parentheses are adjusted for (primary) school level clustering. 
Map 1 - Tel Aviv School District 1-9, Giv`ataim, and Ramat Gan

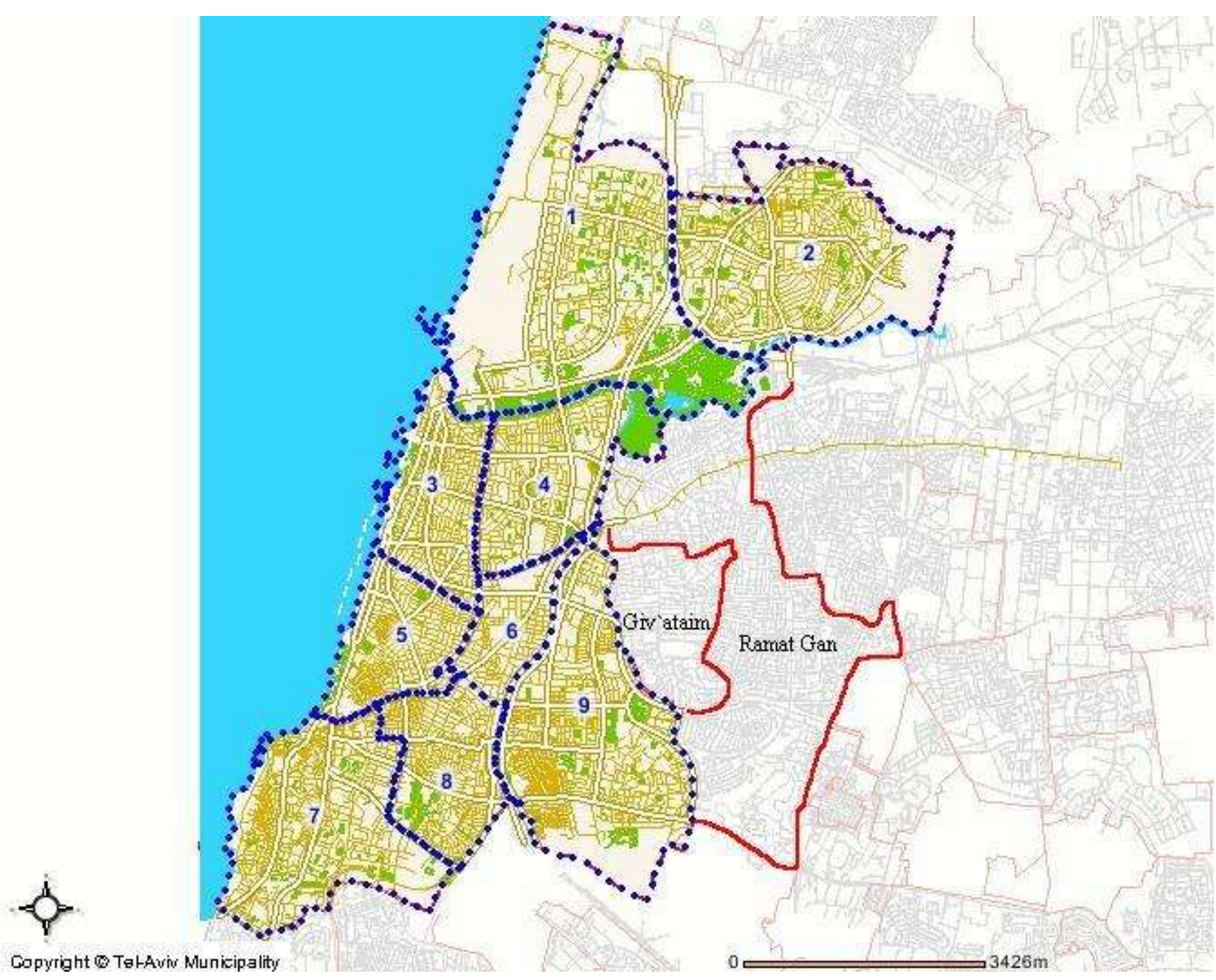


Map 2 - Tel Aviv School District 9 and Tangent Neighborhoods of Giv`ataim and Ramat Gan.

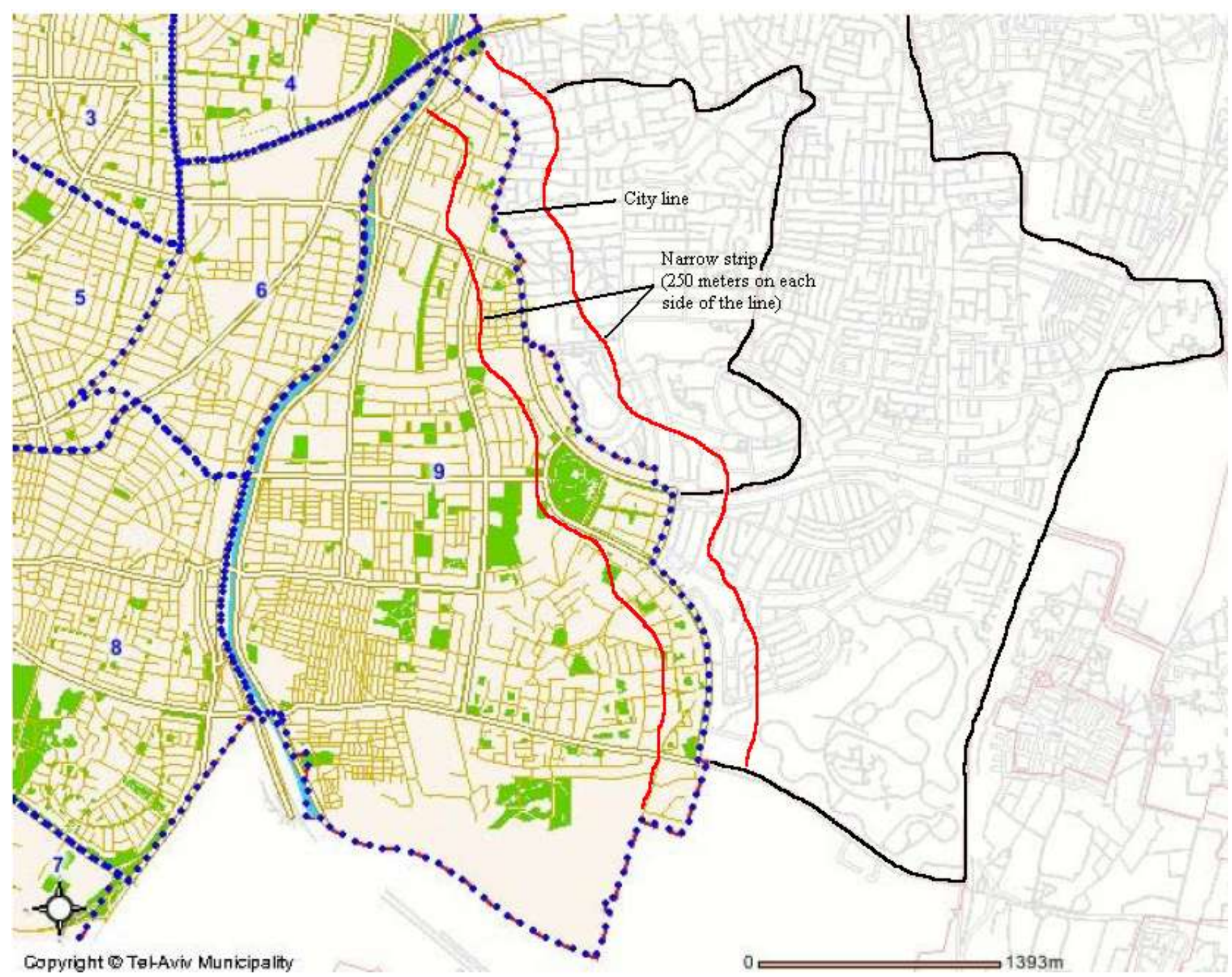

Note: The red lines are illustrative and not precise. 